\title{
DESENVOLVIMENTO DA CULTURA DO MILHO EM DIFERENTES CONDIÇÕES DE DRENAGEM SUBTERRÂNEA, NO VALE DO RIBEIRA
}

\section{EMILIO SAKAI}

Engenheiro Agrônomo

Orientador: Prof. Dr. NILSON A. VILLA NOVA

Tese apresentada à Escola Superior de Agricultura "Luiz de Queiroz", da Universidade de São Paulo, para obtenção do título de Doutor em Agronomia, área de concentração: Solos e Nutrição de Plantas.

PIRACICABA

Estado de São Paulo - Brasil

Fevereiro - 1996 
Dados Internacionais de Catalogação na Publicação (CIP)

DIVISÃO DE BIBLIOTECA E DOCUMENTAÇẪO - Campus "Luiz de Queiroz"/USP

Sakai, Emilio

Desenvolvimento da cultura do milho em diferentes condições de drenagem subterrånea, no Vaie do Ribeira / Emilio Sakai. - - Piracicaba, 1996.

102p. : il.

Tese (doutorado) - - Escola Superior de Agricultura Luiz de Queiroz, 1996.

Bibliografia.

1. Drenagem - Rio Ribeira (Vale) 2. Milho - Produtividade - Rio Ribeira (Vale) 1. Título

2 CDD 633.15 


\section{DESENVOLVIMENTO DA CULTURA DO MILHO EM DIFERENTES CONDIÇÕES DE DRENAGEM SUBTERRÂNEA, NO VALE DO RIBEIRA}

EMILIO SAKAI

Aprovado em: 28.06.1996

Comissão julgadora:

Prof. Dr. NILSON AUGUSTO VILLA NOVA …................................... ESALQ/USP

Prof. Dr. VALTER BARBIERI ..............................................................., ESALQ/USP

Prof. Dr. MARCOS VINICIUS FOLEGATTI ........................................ ESALQ/USP

Prof. Dr. JOSÉ RENATO ZANINI ....................................................... FCAVJ/UNESP

Dr. FLÁVIO BUSSMEYER ARRUDA …........................................... IAC

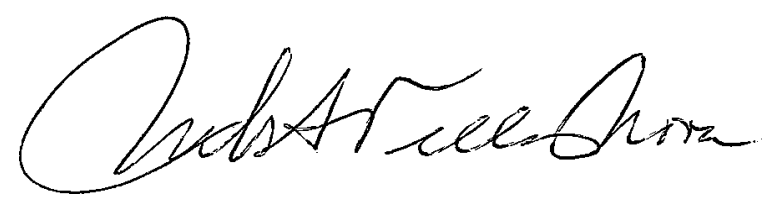

Prof. Dr. NILSON A. VILLA NOVA Orientador 
Aos meus pais

GORO e TAKECA (in memorian)

pelo exemplo de vida e incentivo

À minha esposa SÔNIA

e aos meus filhos

GISELE, VIVIEN E RAFAEL

pelo amor e compreensão

dedico este trabalho. 


\section{AGRADECIMENTOS}

Ao professor Dr. Nilson Augusto Villa Nova, pela orientação precisa e apoio irrestrito durante todas as fases deste trabalho;

Ao Instituto Agronômico do Estado de São Paulo (IAC), pela liberação concedida para a realização deste curso;

Ao Curso de Pós-Graduação em Solos e Nutrição de Plantas da ESALQ/USP, pela possibilidade em realizar o curso;

À Coordenação de Aperfeiçoamento de Pessoal de Nível Superior (CAPES), pela concessão de bolsa de estudo;

À Estação Experimental de Pariquera Açu do Instituto Agronômico, pelas infraestrutura e facilidades oferecidas;

À Seção de Climatologia Agrícola do Instituto Agronômico, pela concessão de dados meteorológicos;

À ZENECA Sementes Ltda, pela doação de sementes de milho;

Aos professores do Curso de Pós-Graduação em Solos e Nutrição de Plantas, pelos ensinamentos;

Ao pesquisador Eduardo Sawazaki, pelo apoio e cooperação durante a realização deste trabalho; 
Aos pesquisadores Luis Alberto Sáes, Mauro Sakai, Flávio Bussmayer Arruda, Mamor Fujiwara, Rinaldo de Oliveira Calheiros, Regina Célia de Matos Pires, pelo excelente ambiente de trabalho, amizade, estímulo e colaboração;

Aos funcionários da Seção de Irrigação e Drenagem e da Estação Experimental de Pariquera Açu do Instituto Agronômico, em especial a Leonice, Carmelina e Antonio, pela cooperação nos trabalhos de campo e laboratório;

A todos que, direta ou indiretamente, contribuiram para realização deste trabalho, o meu sincero agradecimento. 


\section{SUMÁRIO}

Página

RESUMO ......................................................................................... vii

SUMMARY ….............................................................................. ix

1. INTRODUÇÃO

2. REVISÃO DE LITERATURA ....................................................... 4

2.1. Drenagem agrícola ............................................................... 4

2.2. Aspectos do lençol freático e sua importância agrícola .................. 7

2.3. Desenvolvimento do sistema radicular ........................................... 12

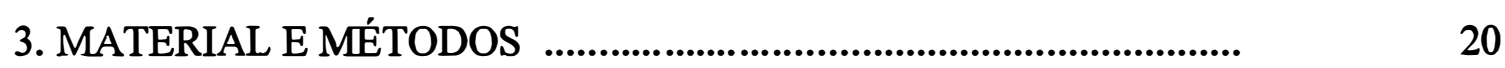

3.1. Local, clima e solo ............................................................... 20

3.2. Condutividade hidráulica do solo .................................................. 27

3.3. Sistema de drenagem subterrânea ............................................... 28

3.4. Poços de observação e tensiômetros ….......................................... 29

3.5. Parcelas experimentais ................................................................ 34

3.6. Cultivo ....................................................................................... 34

3.7. Crescimento da cultura ................................................................. 36

3.7.1. Índice de área foliar ..................................................... 37

3.7.2. Partição da matéria seca ..................................................... 38

3.7.3. Taxa de crescimento da cultura ...................................... 39

3.7.4. Eficiência na conversão de matéria seca em grãos ............... 39

3.7.5. Resistência estomática à difusão de vapor d'água ................ 40

3.7.6. Profundidade efetiva do sistema radicular .......................... 41

3.8. Análise de produção ..................................................................... 42 
Página

4. RESULTADOS E DISCUSSÃO

4.1. Nível do lençol freático

4.1.1. Determinação do lençol freático: Método do poço vs Método proposto

4.2. Crescimento da cultura

4.2.1. Altura e recobrimento do solo pelas plantas

4.2.2. Índice de área foliar

4.2.3. Desenvolvimento da matéria seca

4.2.3.1. Folha

4.2.3.2. Colmo

4.2.3.3. Brácteas, Ráquis e Grãos

4.2.3.4. Peso da matéria seca total

4.2.4. Eficiência na conversão de matéria seca em grãos

4.3. Índice de Estresse de Água

4.4. Sistema Radicular

4.4.1. Densidade de comprimento

4.4.2. Profundidade efetiva 
DESENVOLVIMENTO DA CULTURA DO MILHO EM DIFERENTES CONDIÇÕES DE DRFNAGEM SUBTERRÂNEA, NO VAIE DO RIBEIRA

Autor: FMIIIO SARAI

Orientador: Prof.Dr. NILSON A. VIIIA NOVA

\section{RESUMO}

As extensas terras de baixada do Vale do Rio Ribeira possivelmente apresentarão boas condições de cultivo, se forem devidamente saneadas e drenadas. Com o intuito de se conhecer melhor essa potencialidade e obterse informações para uso em projetos, foi conduzido um ensaio de campo com a cultura do milho na E.E. de Pariquera Açu do Instituto Agronômico do Estado de São Paulo (IAC). Numa área de solo orgânico, foram estabelecidos os sistemas de drenagem subterrânea compostos de tubos corrugados envoltos em material filtrante instalados na profundidade de $1,00 \mathrm{~m}$, com declive de $0,002 \mathrm{~m} \cdot \mathrm{m}^{-1}$, nos 
espaçamentos de $3,6,9,12$ e $18 \mathrm{~m}$, que constituiram os tratamentos do presente estudo.

o método do tensiômetro proposto para o monitoramento do lençol freático mostrou-se confiável e adequado ao uso em experimentação agrícola. As maiores diferenças entre tratamentos foram da ordem de $15 \mathrm{~cm}$ na profundidade do lençol freático.

A utilização do conceito de "Somatório de Excesso de Água", $\mathrm{SEW}_{30}$, para quantificar $\circ$ efeito do lençol freático acima da profundidade crítica de $30 \mathrm{~cm}$, produziu uma relação hiperbólica decrescente com a produção final. Relação similar foi obtida com o Indice Diário de Estresse, SDI, porém a significância estatística foi menor que a obtida para $\mathrm{SEW}_{30}$.

O melhor desempenho foi observado no tratamento com drenos espaçados a 3m, atingindo a 7,3 t.ha ${ }^{-1}$ de produção final. O aumento no espaçamento entre drenos resultou em pequena redução nos parâmetros de crescimento e produção da cultura. Porém, as maiores diferenças foram da ordem de 10\%, como na produção final de grãos.

A profundidade efetiva máxima da cultura do milho foi de $39 \mathrm{~cm}$ nos tratamentos de 3,6 e $9 \mathrm{~m}$ e diminuiu em torno de $20 \%$ nos de maiores distâncias. 


\section{GROWTH OF MAIZE UNDER SEVERAL DRAINED FIELD}

\section{CONDITIONS, IN THE RIBEIRA VALLEY}

Author: BMIIIO SARAI

Adviser: Prof. Dr. NIISON A. VIIIA NOVA

\section{SUMMARY}

Large underdeveloped low land area is still available in the Ribeira Valley, which might present good conditions for an intensive agriculture if properly drained. This work had the purpose to know the production level and preliminary information for using in drainage projects.

A field experiment with maize was conduced during the rainy season of 1994, at the Experimental Station of Pariquera Açu of the Agronomic Institute (IAC) of São Paulo State, Brazil.

A subsurface drainage system was established in an area of organic-mineral soil at $1.0 \mathrm{~m}$ deep and slope of $0.002 \mathrm{~m} . \mathrm{m}^{-1}$, with five treatments of drain spacing: $3.0,6.0$, $9.0,12.0$, and $18.0 \mathrm{~m}$. 
A proposed tensiometric method for evaluating the water table depth showed to be adequate for using in field experimentation. The largest differences of water table depth among treatments were, in average; $0.15 \mathrm{~m}$.

The crop performance was best on the treatment with $3.0 \mathrm{~m}$ of drain spacing, with a $7.3 \mathrm{t} / \mathrm{ha}$ of final grain yield, considered very high for the regional standard. Increasing the drain distance resulted in a small reduction on plant development and productivity. The largest difference was around $10 \%$, measured on final grain yield.

The concept of Sum of Excess of Water, $\mathrm{SEW}_{30}$, was used to quantify the effect of water table above $30 \mathrm{~cm}$ depth. It produced a decreasing hyperbolic relation with final yield. Similar relation was obtained with Stress Day Index, SDI, except that its significance was slightly smaller than the former.

The maximum effective root depth of maize reached to $0.39 \mathrm{~m}$ in the $3.0,6.0$ and $9.0 \mathrm{~m}$ treatments, and it was reduced about $20 \%$ as the drain spacing was increased. 


\section{INTRODUÇÃO}

A região paulista do Vale do Rio Ribeira de Iguape compreende uma área de 1.709 .000 ha de terra com topografia predominantemente montanhosa, englobando cerca de 200.000 ha de várzea.

Nessa região, os solos de várzeas na sua maioria desenvolveram-se a partir de sedimentos fluviais holocênicos, variavelmente argilosos, silto-argilosos e areno-argilosos, e por depósitos orgânicos ou turfas (LEPSCH et al., 1990), caracterizando-se por apresentar uma grande variabilidade espacial.

A ampliação de fronteiras agrícolas com o avanço sobre essas terras de difícil manejo tem levado a frustrações. Muitos desses casos são empreendimentos que poderiam ser viáveis, visto que os solos apresentam algumas características que os tornam adequados à prática de agricultura de alta produtividade. A proximidade de água, condição essencial para a própria existência da várzea, faz com que mesmo sem irrigação suas áreas sejam mais úmidas do 
que as partes mais altas. Esse fator elimina por um lado os problemas de déficit hídricos causados por veranicos e estiagem por período prolongado. Por outro lado, o excesso de água no solo devido aos altos níveis estacionais ou periódicos do lençol freático, nas estações das chuvas, provoca o encharcamento da zona radicular, diminuindo a aeração do solo e a capacidade de absorção de água e nutrientes pelas plantas causada pela falta de oxigênio tornando-o mais prejudicial que o estresse causado pela falta de água.

Alguns critérios têm sido mencionados na literatura para a obtenção de coeficientes utilizáveis em projetos de drenagem. Mas invariavelmente eles se baseiam em condições artificiais de homogeneidade de solo e de lençol freático constante por um determinado período. Essas hipóteses não representam as condições existentes na prática, portanto, não confiáveis.

Em vista da grande variabilidade espacial dos solos de várzea observada nas planícies aluvionais do Vale do Ribeira devido a processos tanto sedimentológicos como pedogenéticos (BERG et al., 1987) é conveniente, para fins de desenvolvimento de métodos de manejo de solos, estudálos em diversos lugares ou evitar o delineamento de sistemas de drenagem com base somente em parâmetros hidrodinâmicos do solo, substituindo-os por outros tão 
importantes quanto a produção de componentes da planta em experimentos de campo, sob condições naturais de flutuações de lençol freático.

Há inúmeros trabalhos de pesquisa conduzidos com o objetivo de determinar a resposta da planta às condições de excesso de água. Observaram-se reduções significativas na produtividade do milho, quando o encharcamento ocorria principalmente durante o estádio vegetativo (RITTER \& BEER, 1969; CHAUDHARY et al, 1975; KANWAR et al, 1988; EVANS et al, 1990).

A presente pesquisa tem por objetivo fornecer parâmetros que indiquem o espaçamento ideal para um sistema de drenagem agrícola e determinar a profundidade efetiva do sistema radicular do milho. Ela foi conduzida em condições de campo, assumindo as seguintes hipóteses:

- os parâmetros produtivos da cultura podem indicar o espaçamento adequado para a instalação de drenos subterrâneos em várzeas ;

- o uso de tensiômetros com líquido manométrico de densidade pouco superior ao da água (de 1,5 a 2,0 ) é adequado para o monitoramento do lençol freático em várzeas;

- a drenagem eficiente possibilita a utilização das várzeas no período das chuvas. 


\section{REVISÃO DE IITERATURA}

A região do Vale do Rio Ribeira de Iguape caracteriza-se pelo clima bastante úmido e pela grande diversidade de terras, quanto ao potencial para as atividades agrícolas.

Segundo o macrozoneamento da região realizada por LEPSCH et al. (1990) cerca de 33\% das terras são aptas para lavoura perene e/ou anuais, ressaltando que 70\% das mesmas tem apenas aptidão regular nos níveis de manejo médio e/ou alto de tecnologia ou capital, sendo de aptidão restrita quando pressupõe baixo nível de emprego de tecnologia. o potencial agrícola dos solos situados nas várzeas está condicionado principalmente aos riscos de inundação ou à possibilidade de drenagem.

\subsection{Drenagem agrícola}

A drenagem em áreas de várzea é complexa, onerosa e muitas vezes não obtem resultados satisfatórios se as 
caracteristicas físicas do solo e do terreno não forem avaliadas cuidadosamente antes de ser instalado um sistema de drenagem. Nessas áreas, para melhor aproveitamento do terreno, facilidade de operações com implementos agrícolas e possibilidade de irrigação "in situ", o método recomendado e mais utilizado no Japão é o sistema de drenagem subterrânea (TABUCHI, 1985).

Para o bom funcionamento de um dreno subterrâneo é necessário que ele esteja conectado a um sistema coletor aberto ou subterrâneo e estes, ligados ao sistema principal de drenagem; a sua eficiência depende do nivelamento, da permeabilidade do material envoltório e do período de drenagem.

De acordo com MOHAMMAD \& SHAGGS (1984), os tubos plásticos devem ter no mínimo $38,5 \mathrm{~cm}^{2}$ de área perfurada por metro de tubo para que tenham boa eficiência. Quando esta área é dobrada, há um aumento na capacidade de absorção da água do solo equivalente ao efeito de um envelope de $5 \mathrm{~cm}$ de cascalho.

Um método simples e vantajoso é o dreno tipo torpedo, embora o seu principal objetivo não é o abaixamento do lençol freático, e sim eliminar o excesso de água da superfície do solo através das frestas produzidas pela haste do implemento. Infelizmente, esse sistema não pode ser operado em condições do Vale do Rio Ribeira pela 
grande incidência de madeiras na subsuperfície do solo, depositadas durante a época da sedimentação e formação do solo.

$$
\text { NASSEHZADEH-TABRIZI \& WILLARDSON }
$$

verificaram que utilizando-se de um sistema de torpedo com haste vibratória produziram fissuras menores, mas estáveis, evitando o colapso precoce dos drenos aumentando a sua vida útil. Esses mesmos autores constataram que com a diminuição da umidade do solo, o torpedo produziu fendas maiores e em maior número, a menos de $24 \%$ de umidade 0 excesso de rachaduras provocou a interrupção dos drenos. Unhanand e Triamsangien (1975) citados por MILLAR (1978) em estudo comparativo para avaliar o sistema combinado de drenagem, constataram que o rebaixamento do lençol freático foi aproximadamente duas vezes maior que no sistema de drenagem por tubos, tendo um rebaixamento maior de 18 a $23 \mathrm{~cm}$, após 5 dias.

Embora alguns autores citem que a durabilidade dos drenos torpedos alcancem até 10 anos, HARRIS (1984) verificou que sua vida útil é bastante reduzida (menos de 3 anos) daí a necessidade de que sejam periodicamente refeitos.

$\mathrm{Na}$ sistematização de terrenos situados em várzeas, normalmente planos, é imprescindível o uso de 
drenos superficiais, preferencialmente, como canais condutores e coletores dos drenos subterrâneos.

No Japão, em tabuleiros de arroz, 70\% da água superficial é retirada pelos drenos abertos após dois dias de descarga, o remanescente $30 \%$ são retidos na desuniformidade do terreno (TABUCHI, 1985).

Segundo WILLARDSON (1982), o coeficiente de drenagem, parâmetro usado no cálculo do espaçamento da drenagem superficial, deve ser desenvolvido no local da experimentação ou através do balanço da água no solo, caso contrário ele não será preciso.

\subsection{Aspectos do lençol freático e sua importância agrícola}

Uma das principais limitações à produção agrícola em solos de várzeas é o excesso de umidade por um período prolongado. Essas limitações não correspondem, necessáriamente, à presença direta do lençol freático ou da umidade excessiva causada pela franja capilar, mas sim, à deficiência de oxigênio no solo ou dissolvido na água, comprometendo ao próprio transporte da solução de nutrientes através do sistema radicular e tornando a planta estressada, suceptível à doenças e à deficiências 
nutricionais. Os encharcamentos temporários, comuns em condições de várzeas, resultados de chuvas intensas, determinam ao sistema radicular das plantas a submeterem-se à respiração anaeróbica, produzindo, consequentemente, apenas uma fração de energia, insuficiente para o metabolismo normal, resultando em mortes prematuras das células das raízes. Segundo SCHILFGAARDE \& WILLIAMSON (1965), as plantas respondem preferencialmente ao nível de aeração na zona radicular e à disponibilidade de água, que ao próprio nível do lençol freático, e enfatizam que informações sobre a variação na concentração de oxigênio no solo e o fluxo da água através da zona radicular constituem medidas necessárias para o estabelecimento de critério para projetos de drenagem. A movimentação da água no perfil permite que ocorram as trocas gasosas do solo, sendo o seu principal mecanismo.

GoINS et al. (1966) constataram que em três solos cujas texturas variavam de areia fina franca a franco argilo siltoso, a produção de colmos de milho aumentou significativamente quando a profundidade do lençol freático aumentou de 15 para $80 \mathrm{~cm}$. A produtividade máxima de milho doce foi obtida quando a profundidade do lençol freático era $80 \mathrm{~cm}$.

De acordo com WILLIAMSON \& KRIS (1970), as máximas produtividades das culturas estão associadas a uma 
profundidade ótima do lençol freático, e isso depende do tipo de solo, da cultura, do clima e da irrigação.

HILER et al. (1971) indicaram que o nivel ótimo do lençol freático em solo franco arenoso para o sorgo foi de $90 \mathrm{~cm}$, no qual obtiveram a máxima produtividade e ótimo teor proteico. Quando o lençol freático foi mantido estático a $30 \mathrm{~cm}$ ou a $60 \mathrm{~cm}$ obtiveram reduções drásticas na produtividade e na qualidade dos produtos. Essas reduções foram atribuidas ao estresse causado pela baixa difusão de oxigênio no sistema radicular, $20 \times 10-8 \mathrm{~g} \cdot \mathrm{cm}^{-2} \cdot \mathrm{min}^{-1} \mathrm{e}$ na faixa de 40 a $90 \times 10^{-8} \mathrm{~g} \cdot \mathrm{cm}^{-2} \cdot \mathrm{min}^{-1}$, respectivamente, para os níveis de 30 e $60 \mathrm{~cm}$ do lençol freático. No entanto, os níveis de difusão obtidos no tratamento $60 \mathrm{~cm}$ parecem ser suficientemente altos para um crescimento adequado da cultura, de acordo com KRAMER (1969).

SINGH \& GHILDYAL (1980) constataram que durante os primeiros estádios de desenvolvimento do milho, uma inundação por $72 \mathrm{~h}$ reduziu significativamente a assimilação de $\mathrm{N}$ e $\mathrm{K}$ ao contrário de $\mathrm{P}$, não afetando a assimilação de Ca e Mg. A taxa de difusão de oxigênio que girava em torno de $83 \times 10^{-8} \mathrm{~g} \cdot \mathrm{cm}^{-2} \cdot \mathrm{min}^{-1}$ decresceu para $3,5 \times 10^{-8}$ $\mathrm{g} \cdot \mathrm{cm}^{-2} \cdot \mathrm{min}^{-1}$ após $72 \mathrm{~h}$ de inundação. Esses mesmos autores observaram uma redução do $\mathrm{pH}$ do solo de 7,0 para 6,5 após 24h de inundação, certamente, pelo aumento da concentração de $\mathrm{CO}_{2}$. RITTER \& BEER (1969) também constataram que 
maiores prejuízos na cultura do milho são causados quando a inundação ocorre nos primeiros estádios de desenvolvimento. Após $72 \mathrm{~h}$ de inundação no estágio de $15 \mathrm{~cm}$ de altura, a produção foi reduzida em 33\% e no de 76 dias após a emergência a diminuição foi de apenas $21 \%$.

Segundo PLANEMAC (1988), o período de 3 dias gastos para o abaixamento do lençol freático a $50 \mathrm{~cm}$ em área de drenagem subterrânea com drenos espaçados de $20 \mathrm{~m}$ reduziu a produção de milho e trigo. Quando para o preenchimento da vala do dreno subterrâneo utilizou-se de material filtrante, o encharcamento desapareceu em dois dias evitando a diminuição na produção. Já, CAVAZZA \& ROSSI PISA (1988) constataram que quando mantem o lençol freático elevado a componente produção de grãos é a mais afetada do que a de palha.

KITAGAWA et al. (1988) verificaram que o intervalo de drenos subterrâneos espaçados de $2 \mathrm{~m}$ resultaram no nível freático a $40-50 \mathrm{~cm}$ de profundidade e quando aumentava esse intervalo para 6m, elevava-se para $30-40 \mathrm{~cm}$, obtendo-se a máxima produtividade de trigo e soja nesse espaçamento. Repetindo essa experimentação, com cenoura, observou a incidência de danos da ordem de 75, 61 e 15\% nas raízes, nas áreas: sem drenagem subterrânea (testemunha), $6 m$ e $2 m$ de intervalo entre drenos, respectivamente. 
KALITA \& KANWAR (1992) pesquisaram o efeito do manejo do lençol freático sobre o processo fotossintético e sobre a produtividade do milho, e constataram um aumento significativo nesta com $\circ$ incremento em profundidade do lençol freático, desde 0,3 a 0,9m. Uma profundidade de 0,2 a $0,3 \mathrm{~m}$ reduziu significativamente a produtividade do milho na estação úmida. As relações entre taxas fotossintéticas e produtividade variaram para estações secas e úmidas e não foram conclusivas.

Em um solo Gley húmico, ANDRADE \& REIS (1992), utilizando-se de um método similar ao "line source", onde em uma área delimitada por dois drenos superficiais, espaçados de 15m, um cheio de água e outro vazio, estabeleceu-se um gradiente freático. Verificaram que os maiores rendimentos de milho foram obtidos onde o lençol freático manteve-se entre 60 a $70 \mathrm{~cm}$ de profundidade TIMSINA et al. (1994) utilizaram-se da técnica de irrigação por aspersão "line-source" para a diferenciação no teor de água do solo em tabuleiros de arroz, e, constataram que o encharcamento do solo afetou adversamente a taxa de acúmulo de matéria seca, a altura da planta, a taxa de crescimento da cultura e o indice de área foliar de 20 a $50 \%, 7$ a $10 \% 20$ a $50 \%$ e 20 a $30 \%$, respectivamente. 


\subsection{Desenvolvimento do sistema radicular}

o crescimento do sistema radicular das culturas anuais raramente continua em todo o ciclo de desenvolvimento. Existem vários trabalhos na literatura mostrando que, no caso dos cereais, esse crescimento continua até a floração e depois cessa (MENGEL \& BARBER, 1974; EVANS \& WARDLAW, 1976). Por outro lado, MCCLURE \& HARVEY (1962) e HURD (1968) relatam que, sob condições favoráveis, o crescimento das raízes continua até o estádio de maturação.

As dificuldades em medir a distribuição das raízes ativas no solo é um dos obstáculos nos estudos dos sistemas radiculares em condições de campo. Em geral, admite-se que correspondem a aquelas de diâmetro inferior a 1,0 mm, o que não deixa de ser um parâmetro arbitrário.

A distribuição de raízes no solo resulta de uma série de processos complexos e dinâmicos, os quais incluem as interações entre $\circ$ ambiente, $\circ$ solo e as plantas em pleno crescimento. Uma vez que a água e os nutrientes são absorvidos pelas raízes, sua concentração, distribuição e atividade (taxa de crescimento e longevidade) dentro do perfil do solo, é em grande parte que determinará a produção das culturas (BROWN \& SCOTT, 1984). 
A conformação do sistema radicular de uma planta depende em primeiro lugar da sua constituição genética. Em condições favoráveis, ela pode desenvolve-lo plenamente, porém, em condições adversas, haverá sensíveis alterações na maneira de distribuição das raízes.

HARDY (1974) definiu o espaço radicular como o volume de solo que possui características convenientes para o desenvolvimento e funcionamento do sistema radicular das plantas, delimitado pelo espaçamento entre plantas no plano horizontal e verticalmente pelos impedimentos dos solos.

o desenvolvimento das raízes e sua atuação como superfície absorvente depende de muitos fatores relativos ao solo que as circundam, especialmente, os que afetam a resistência mecânica, a umidade, a aeração e a fertilidade do solo (KRAMER, 1969; BROWN \& SCOTT, 1984).

Em função dos processos pedogenéticos ou decorrentes do seu manejo inadequado, num perfil de solo podem aparecer camadas com diferentes graus de compacidade, chegando ao ponto de limitar a penetração e desenvolvimento das raízes ou restringir o fluxo de água e ar. Em amostras de Latossolo Roxo e Podzólico Vermelho compactados artificialmente e cultivados com arroz, GROHMANN \& QUEIROZ NETO (1966) verificaram que não houve desenvolvimento do sistema radicular quando a densidade do solo era de 1,42 e 1,38 $\mathrm{g} . \mathrm{cm}^{-3}$, respectivamente. Já, SHARMA \& SINGH (1969) 
utilizando-se do mesmo procedimento com um solo de textura franco argilo arenoso, constataram que o máximo impedimento ao desenvolvimento radicular do milho foi quando a desnsidade do solo atingiu $1,8 \mathrm{~g} \cdot \mathrm{cm}^{-3}$.

BACCHI (1976), em um trabalho em que o solo foi compactado artificialmente, concluiu que as camadas dentro do perfil causam mais distúrbios ao crescimento de raízes, do que perfis homogêneos com maior densidade. A camada compactada provocou a concentração das raízes na superfície, mas como as condições de umidade do solo e fertilidade eram satisfatórias, as restrições ao crescimento das raízes não tiveram efeito na produção, o que demonstra que nem sempre existe uma relação direta entre produção e crescimento de raízes.

A aeração do solo é outro fator importante no desenvolvimento do sistema radicular e por consequência, da planta. Na ausência de oxigênio predominam as reações anaeróbicas com formação de compostos reduzidos, interferindo no $\mathrm{pH}$ e na disponibilidade de nutrientes no SOlo (PONAMPERUMA, 1955).

No entanto, alguns trabalhos têm evidenciado que a diminuição da penetração de raízes está relacionada, principalmente, com a resistência que o solo compactado oferece a ser deslocado pelas raízes, e não às diferenças na sua densidade, conteúdo de água ou de ar (BLACK, 1975; 
TACKETT \& PEARSON, 1964). Segundo esses últimos autores, em certos casos, a aeração pode chegar a níveis tão baixos e a resistência tão alta, que quaisquer destes fatores, em separado, podem impedir a penetração.

De acordo com KRAMER (1969), existem muitas informações contraditórias em relação aos níveis de $\mathrm{O}_{2}$ e $\mathrm{CO}_{2}$ que resultem em limitações para o crescimento de raízes, visto que, as diferentes espécies de plantas não respondem umiformemente às variações do meio, tão pouco tem o mesmo comportamento ao longo do ciclo. No entanto, de um modo geral, valores superiores a 40 × $10^{-8} \mathrm{~g} \cdot \mathrm{cm}^{-2} \cdot \mathrm{min}^{-1} \mathrm{de}$ coeficientes de difusão de oxigênio são suficientemente altos para o crescimento adequado.

o conteúdo de água no solo é um dos fatores que mais afeta o crescimento radicular. Considera-se que a taxa de crescimento é máxima no teor de água volumétrica da capacidade de campo $(33 \mathrm{kPa})$, e cessa o crescimento no ponto de murcha (1500 kPa) (MACKAY \& BARBER, 1985). Segundo esses mesmos autores, quando a água disponível era de 60\% da capacidade de campo, a taxa de crescimento de raízes foi de $70 \%$ do máximo e quando a umidade era maior nas camadas profundas, também foi maior o crescimento das raízes nessas camadas.

Tem sido mostrado que o teor de água no solo é o principal fator que afeta a taxa de crescimento de raízes 
(BARBER et al., 1988). De acordo com KRAMER (1969), a água não afeta diretamente as raízes como mostra o seu vigoroso crescimento em soluções nutritivas bem aeradas, porém, um excesso de água no solo desloca o ar do espaço poroso não capilar e produz uma deficiência de oxigênio levando muitas raízes à morte.

FOLLETT et al.(1974) pesquisando a distribuição das raizes de milho no perfil de um solo arenoso sob condições de lençol freático em declínio, variando de 1,33 a 2,64m, observaram que o crescimento foi máximo para a profundidade intermediária.

ROSSI \& MUNDSTOCK (1980), ao estudarem o desenvolvimento de raízes de milho em função de níveis de drenagem no solo, observaram que, com a elevação do lençol freático até a superfície, portanto, com severas restrições de aeração, $90 \%$ do peso e $85 \%$ do comprimento das raízes se concentraram na profundidade $0-15 \mathrm{~cm}$.

Em experimentação de campo em solo aluvial, ALVINO \& ZERBI (1986) verificaram o efeito do lençol freático sobre parâmetros de produção de milho, sob condições de precipitações naturais e irrigação. Constataram que, mesmo com lençol freático a $60 \mathrm{~cm}$ de profundidade, a cultura respondeu a irrigações com o aumento na produtividade pelo maior número de sementes por espiga e diminuição na senescência precoce das folhas. 
Se por um lado o abaixamento do lençol freático propicia melhores condições de aeração do solo, por outro, aumenta $\circ$ risco a suscetibilidade à seca pelas plantas quando excessivo.

REICOSKY et al.(1976) trabalhando com plantas de milho em um solo areno-argiloso, subsolado até a profundidade de $38 \mathrm{~cm}$ e comparando com as cultivadas convencionalmente, verificaram que, com um lençol freático a $80 \mathrm{~cm}$ da superfície, a subsolagem resultou em maior profundidade de enraizamento, provocando, consequentemente, maior habilidade para a planta na utilização de água capilar acima do lençol freático.

CRUCIANI (1981) verificou que para a cultura do milho e trigo o estádio crítico às inundações é o florescimento, tendo havido um decréscimo na produtividade em relação às testemunhas de $32,6,39,2$ e 43,5\% para o trigo e de $43,0,60,6$ e $68,9 \%$ para $\circ$ milho, com respectivamente 3,6 e 9 dias de inundação. Sugere, ainda, - autor que o tempo de drenagem da zona radicular dessas culturas deve ser inferior a três dias.

TIMSINA et al. (1994) constataram que mantendo o solo saturado a densidade do sistema radicular estavam concentrados nos primeiros $0,10 \mathrm{~m}$ durante 0 estádio vegetativo do feijão caupi, provavelmente, devido ao déficit na taxa de oxigênio em profundidade. 
QUAGGIO et al. (1991) observaram em um Cambissolo álico que, nas áreas tratadas quatro anos antes com doses de calcário superiores a $9 \mathrm{t}_{\mathrm{h}} \mathrm{a}^{-1}$ as raízes de milho atingiram até $100 \mathrm{~cm}$ de profundidade, ao passo que nas parcelas sem calcário o sistema radicular ficou restrito aos $20 \mathrm{~cm}$ superficiais, onde a presença de maiores teores de matéria orgânica reduziram o efeito tóxico do alumínio.

KLEPKER \& ANGHINONI (1995), em experimentação conduzida em vaso, sob condições controlada de casa de vegetação, constataram que o rendimento de matéria seca, a concentração de fosforo no tecido do milho e a relação parte aérea/raiz aumentaram com o nível de fósforo extraível do solo.

No Brasil, os primeiros trabalhos para a determinação do sistema radicular de plantas cultivadas foram conduzidos pelo Dr. Romeu Inforzato, do IAC, tendo publicados inúmeros artigos até os anos 70. Uma compilação desses dados é apresentado por ARRUDA (1987), que mostra uma forte concentração de raízes nos primeiros 30 ou $40 \mathrm{~cm}$ de profundidade, para solos do Estado de São Paulo.

Segundo BOHM (1979), a pesquisa sobre o sistema radicular de plantas está na fase inicial da ciência, e acrescenta que a razão disso é basicamente por causa da metodologia. Os métodos conhecidos, diz o autor, são tediosos, consomem muito tempo e a exatidão de seus 
resultados, com frequência, não é muito grande, levando a muitos pesquisadores a não realizar tal tipo de estudo.

De um modo geral, pode-se dizer que os métodos mais precisos são mais trabalhosos. Para a seleção do melhor método de estudo em um caso particular é preciso além de estar familiarizado, saber quanto tempo e trabalho serão necessários para obter os resultados desejados.

Por fim, para modificar a zona de raízes, visando a melhorar o suprimento e a disponibilidade de nutrientes para as plantas, pode-se lançar mão de diversos meios: 1) aplicação de calagem e fertilizantes nas suas diversas formas; 2) seleção de culturas, visando maior penetração de raízes, espécies e cultivares mais adaptados, rotação e cultivos múltiplos; e 3) através do uso de equipamentos, com método convencional, subsolador, plantio direto ou cultivo mínimo (SUMNER \& BOSWELL, 1981). Nesta empreitada, investiu-se na drenagem subterrânea de várzea e em metodologia prática de acompanhamento do lençol freático. 


\section{MATERIAL E MÉTODOS}

\subsection{Local, clima e solo}

A experimentação foi desenvolvida em condições de campo na várzea "polderizada" da Estação Experimental de Pariquera Açú, pertencente ao Instituto Agronômico do Estado de São Paulo (IAC), no período de março de 1993 a março de 1995, cujas coordenadas geográficas são $24^{\circ} 35^{\prime}$ de latitude sul e $47^{\circ} 50^{\prime}$ de longitude Oeste de Greenwich e altitude de 14 metros.

O clima da região conforme classificação de Koppen é do tipo "Cfa", definido como tropical úmido, sem estação seca, sendo a temperatura do mês mais quente superior a $22^{\circ} \mathrm{C}$ e o total de chuvas do mês mais seco superior a $30 \mathrm{~mm}$. A precipitação pluvial anual é de $1587 \mathrm{~mm}$ e a evapotranspiração potencial de $1140 \mathrm{~mm}$, excedente hídrico de $447 \mathrm{~mm}$ e deficiência hídrica nula. A temperatura média do verão é $25,6^{\circ} \mathrm{C}$ e do inverno, $19,1{ }^{\circ} \mathrm{C}$. As informações meteorológicas foram fornecidas pela seção 
de Climatologia Agrícola do IAC e coletadas no Posto Agrometeorológico localizado na Estação Experimental de Pariquera Açu, Tabela 1.

A formação geomorfológica da área em estudo é composta de sedimentos holocênicos e dado às características fisiográficas de várzea originou os solos classificados por SAKAI \& LEPSCH (1984) como sendo Orgânico, álico. A composição granulométrica expressa em relação a solo isento de matéria orgânica, porosidade e densidade global dos solos são apresentados na Tabela 2, extraídos do perfil representativo da área e complementados com as determinações realizadas em amostras indeformadas tomadas em trincheiras até a profundidade de $60 \mathrm{~cm}$. A caracterização da curva de retenção de água fez-se através da correlação entre a umidade observada e a pressão aplicada através da Câmara de Richards em amostras indeformadas de solo, Figura 1.

Ao implantar o sistema de drenagem subterrânea, as análises químicas indicavam baixa saturação por bases trocáveis e elevada acidez do solo. A necessidade de calagem determinada pelo método de índice de saturação por bases para o cultivo do milho (RAIJ et al. 1985) era de 6,0 t.ha ${ }^{-1}$. No entanto, mesmo com essa incorporação ao solo, as análises químicas de amostras coletadas logo após a retirada da cultura e apresentadas na Tabela 3, indicam que 
não foram suficientes para a elevação da saturação por bases a níveis desejados, ficando os valores em torno de 52\% na camada superficial $(0-20 \mathrm{~cm})$ e de $42 \%$ na subsuperficial $(20-40 \mathrm{~cm})$. Embora medianamente providos por bases, apresentou uma relação desfavorável para potássio. A acidez, como era de se esperar para solos com altos teores de matéria orgânica, manteve-se alta. 
0
0
0
0
0
0
-1
01
0
0

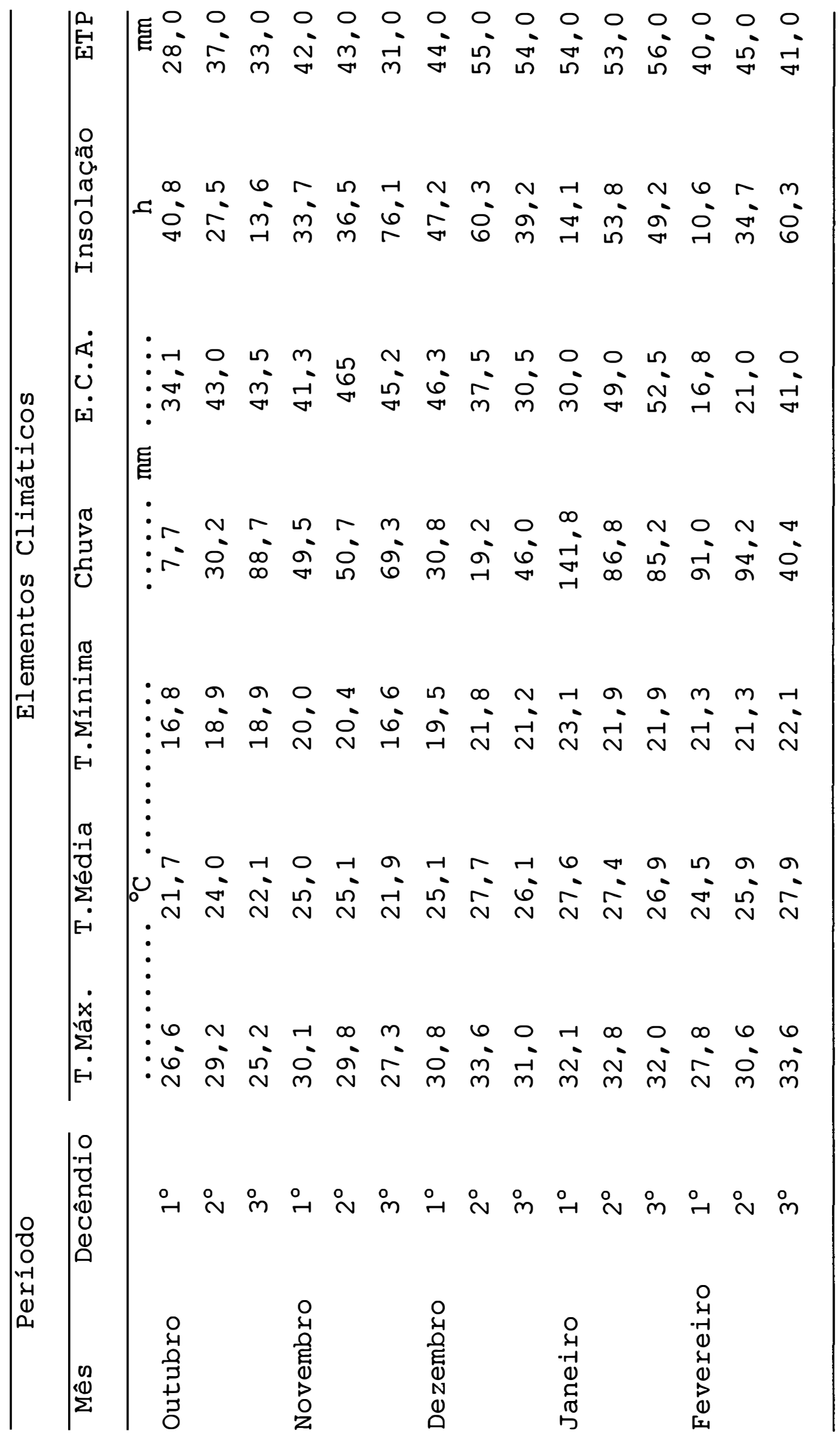


TABELA 2 - Características físicas do solo da área
experimental, Pariquera Açu, 94/95

\begin{tabular}{|c|c|c|c|c|c|}
\hline \multirow[b]{2}{*}{ Prof. } & \multicolumn{3}{|c|}{ Composição granulométrica } & \multicolumn{2}{|c|}{ Densidade } \\
\hline & $\overline{\text { Argila }}$ & Silte & Areia. & Global. & Particula \\
\hline $\mathrm{Cm}$ & $\%$ & $\%$ & $\%$ & $\mathrm{~g} \cdot \mathrm{Cm}^{-3}$ & $\mathrm{~g} \cdot \mathrm{Cm}^{-3}$ \\
\hline $0-10$ & 57 & 28 & 15 & ... & ... \\
\hline $10-32$ & 68 & 27 & 5 & 0,56 & 1,9 \\
\hline $32-68$ & 70 & 21 & 9 & 0,46 & 2,0 \\
\hline $68-110$ & 75 & 19 & 6 & 0,45 & 2,4 \\
\hline
\end{tabular}

Porosidade Total Umidade volumétrica Porosidade drenável

$(\%)$

à tensão de $-0,3 \mathrm{KPa}$

(\%)

61

44

17

61

44

17

66

45

21

76

... 


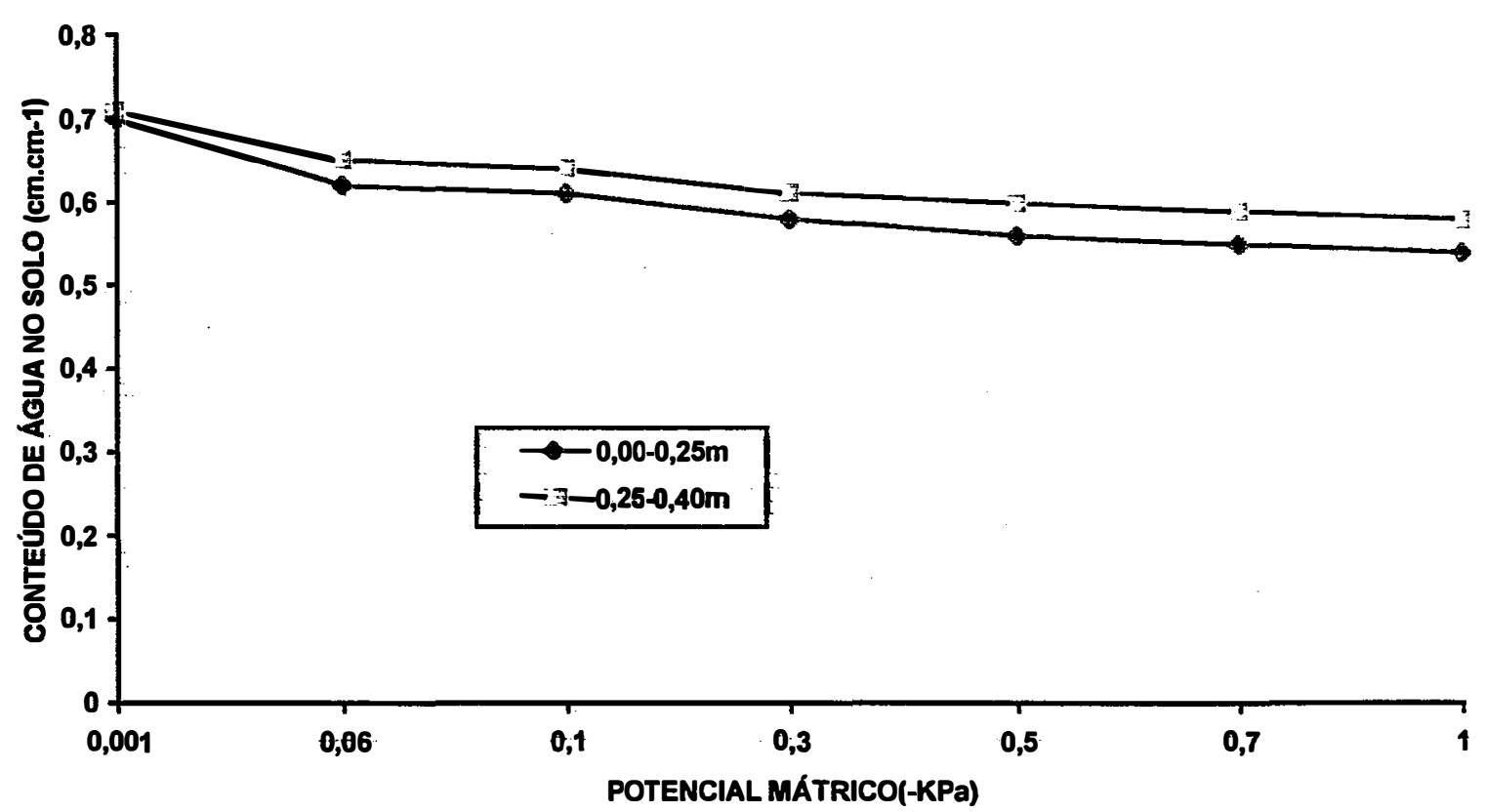

FIGURA 1 -Curvas caracteristicas de umidade no solo da área experimental, Pariquera Açu, 94/95. 
TABELA 3. Caracteristicas químicas do solo da área experimental após a colheita do milho, média \pm erro padrão da média. Pariquera Açu, 94/95.

\begin{tabular}{lccr}
\hline Prof. (cm) & $\mathrm{pH}^{-\mathrm{CaCl}_{2}}$ & M.O. (\%) & P (ppm) \\
\hline $0-20$ & $4,5 \pm 0,2$ & $9,3 \pm 0,1$ & $45 \pm 17$ \\
$20-40$ & $4,4 \pm 0,1$ & $9,5 \pm 0,5$ & $27 \pm 4$ \\
\hline
\end{tabular}

\begin{tabular}{|c|c|c|}
\hline $\mathrm{Ca}^{2+}$ & $\mathrm{Mg}^{2+}$ & $\mathrm{K}^{+}$ \\
\hline
\end{tabular}

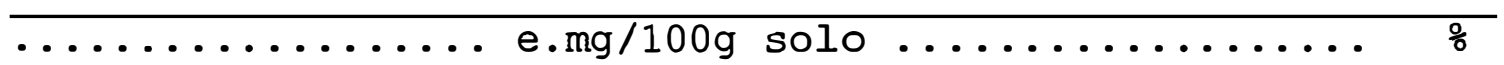

$10,9 \pm 4,8 \quad 2,1 \pm 0,6 \quad 0,11 \pm 0,01 \quad 9,8 \pm 1,5 \quad 13,2 \pm 5,4 \quad 23,0 \pm 4,6 \quad 52 \pm 10$

$6,0 \pm 1,0 \quad 1,6 \pm 0,2 \quad 0,12 \pm 0,01 \quad 11,1 \pm 1,6 \quad 7,8 \pm 1,2 \quad 18,7 \pm 0,5 \quad 42 \pm 7$

* $\mathrm{S}=$ Soma de bases trocáveis

** CTC= Capacidade de Troca Catiônica

$\star \star \star \mathrm{V} \%=\mathrm{S} / \mathrm{CTC} \star 100$ 


\subsection{Condutividade hidráulica do solo}

Antes da instalação do sistema de drenagem subterrânea, realizaram-se testes de condutividade hidráulica do solo saturado (Ko), utilizando-se do método tradicional "auger-hole", para estudos de drenagem subterrânea. Para a caracterização detalhada da área, foram avaliados 25 locais, abrangendo toda a extensão do terreno. No cálculo de Ko, utilizou-se o método de Ernst (1950) apresentada por MILLAR (1978), para condição em que a distância entre o fundo do poço e a camada impermeável é maior que a metade da distância entre o nível freático e o fundo do poço, conforme a expressão:

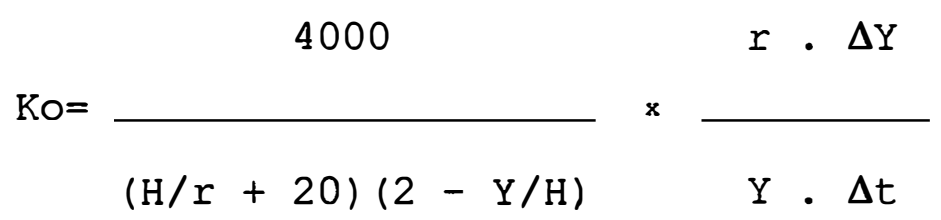

onde:

Ko - condutividade hidráulica do solo saturado, (m.dia ${ }^{-1}$ );

H - profundidade do poço, abaixo do nível freático, (cm);

Y - distância entre o nível freático e o ponto médio dos níveis de água no intervalo de tempo $\Delta t,(\mathrm{~cm})$;

$r$ - raio da perfuração feito pelo trado, (cm);

$\Delta Y$ - intervalo de altura no tempo $\Delta t,(\mathrm{~cm})$;

$\Delta t$ - intervalo de tempo entre duas leituras, (dia). 
Como era de se esperar para solos de várzea, os resultados dos testes indicaram uma grande variabilidade espacial na condutividade hidráulica do solo saturado (Ko), cujo valores variaram entre 0,03 a 0,20 m.dia ${ }^{-1}$.

\subsection{Sistema de drenagem subterrânea}

No planejamento do sistema de drenagem subterrânea, inicialmente, o critério adotado para definição dos tratamentos, o espaçamento entre drenos seria em função da velocidade de rebaixamento do nível freático após recarga, do tempo de tolerância e da profundidade efetiva do sistema radicular da cultura. No entanto, após as determinações preliminares da condutividade hidráulica, na dificuldade de estabelecimento de espaçamentos cujo valores fossem múltiplos para fins de análise, optou-se por fazer cinco tratamentos com as seguintes medidas entre os drenos subterrâneos: 3, 6, 9, 12 e 18m. Devido ao planejamento da sistematização da área, o comprimento dos tubos foi de 100m.

Portanto, as quadras foram dimensionadas em $36 \mathrm{x}$ 100m em função do maior espaçamento. Assim, para a instalação dos tratamentos propostos, foram necessários, 
respectivamente, 12, 6, 4, 3 e 2 linhas de tubos corrugados enterrados em cada quadra. Essas áreas foram posteriormente subdivididas em parcelas, para avaliação da variabiidade dos resultados obtidos.

Assim, o sistema de drenagem subterrânea foi constituído de uma malha de tubos corrugados flexíveis de 0,06m de diâmetro, instalados a uma profundidade de 0,80 a $1,00 \mathrm{~m}$ e envoltos numa manta de bidim OP-20, areia grossa e capim colonião, locada perpendicularmente ao dreno coletor superficial. O gradiente de instalação dos drenos foi de $0,002 \mathrm{~m} \cdot \mathrm{m}^{-1}$. Na saída, os drenos subterrâneos foram conectados a registros de esfera de $0,06 \mathrm{~m}$ através de tubos rígidos de PVC para fins de manejo do lençol freático.

\subsection{Poços de observação e tensiômetros}

Foram instaladas 3 linhas de poços de observação para cada tratamento entre dois drenos consecutivos para fins de configuração do nível freático, através de medidas de cargas hidráulicas em função do tempo. Para os tratamentos de espaçamento maiores (18 e $12 \mathrm{~m})$ foram instalados 5 poços por linha, e nos demais 3, sendo, um na 
posição central entre dois drenocutivos, 2 juntos aos drenos e os outros na posição liária.

Os poços foram abertos co tipo australiano de $0,075 \mathrm{~m}$ de diâmetro até a profu média de $1,80 \mathrm{~m}$ e internamente protegidos com tubo: rígido $0,05 \mathrm{~m}$ de diâmetro, fendilhados com serra ţido com manta de bidim e areia grossa. Os tubos oficaram com 0,20m acima da superfície e nivelados sí, servindo como referencial para o nível do lençolco.

Distante $1,00 \mathrm{~m}$ e parale: à linha de poços de observação foram instalados tenios comuns, do tipo de coluna de mercúrio, com 1,00m primento e suporte de leitura para até $2,00 \mathrm{~m}$ dela. No recipiente originalmente utilizado com o mercile foi substituído por um líquido para colunas manomí de densidade 1,5 $\mathrm{g} \cdot \mathrm{cm}^{-3}$. Para que o equilíbrio entria do tensiômetro e a do lençol freático proceş rápidamente, os tensiômetros também foram instaladłoços.

As leituras dos níveishgua nos poços de observação, assim como a do nívelíquido manométrico nos tensiômetros instalados para fi acompanhamento da flutuação do lençol freático fœalizadas em dias

\footnotetext{
${ }^{1}$ Para referência do leitor o líquido para colunas manométrioirido na firma SALVI CASAGRANDE-Medição e Automatização Ltda. Rua Florêneu, 605, São Paulo-SP
} 
alternados. Quando ocorria uma recarga natural procedia-se leituras diárias.

o método proposto para determinação do lençol freático por tensiômetros, com leituras realizadas através de líquido manométrico de densidade $1,5 \mathrm{~g} \cdot \mathrm{cm}^{-3}$, baseia-se no equilíbrio entre a água do lençol freático/solo e a do tensiômetro (Figura 2).

Assim, em uma determinada profundidade $x, 0$ potencial matricial ou de pressão, em unidade de carga hidráulica, é:

$$
\psi_{\mathrm{m}}=-\left(13,6 \mathrm{~h}-\mathrm{h}-\mathrm{h}_{1}-\mathrm{h}_{2}\right)
$$

ou

$$
\psi_{\mathrm{m}}=-12,6 \mathrm{~h}+\mathrm{h}_{1}+\mathrm{h}_{2}
$$

onde:

$$
\begin{aligned}
\mathrm{h}= & \text { leitura em } \mathrm{cm} \text { de } \mathrm{Hg} ; \\
\mathrm{h}_{1}= & \text { altura do manômetro em relação à superfície do solo; } \\
\mathrm{h}_{2}= & \text { profundidade da cápsula porosa em relação à } \\
& \text { superfície do solo. }
\end{aligned}
$$

Substituindo o $\mathrm{Hg}$ por outro líquido manométrico de densidade de $1,5 \mathrm{kgf} \cdot \mathrm{dm}^{-3}$, e supondo que, sobre a cápsula porosa do tensiômetro há uma lâmina $\left(\mathrm{h}_{2}-\mathrm{H}\right)$ do lençol freático (Figura 2), onde, nessas condições o potencial 
matricial é nulo, e atua sobre a mesma uma pressão de mesma intensidade $\left(\mathrm{h}_{2}-\mathrm{H}\right)$, temos:

$$
\psi_{\mathrm{m}}=-\left(1,5 \mathrm{~h} *-\mathrm{h}^{*}-\mathrm{h}_{1}-\mathrm{h}_{2}\right)-\left(\mathrm{h}_{2}-\mathrm{H}\right)=0
$$

ou

$$
\psi_{\mathrm{m}}=-0,5 \mathrm{~h}^{\star}+\mathrm{h}_{1}+\mathrm{H}=0
$$

nessas condições,

$$
H=0,5 h^{*}-h_{1}
$$

onde:

$$
\begin{aligned}
& \mathrm{h} *=\text { leitura em } \mathrm{cm} \text { do líquido manométrico; } \\
& \mathrm{H}=\text { é a profundidade do lençol freático em } \mathrm{cm} \text {. }
\end{aligned}
$$

Para lençol freático flutuando abaixo de 80 a $90 \mathrm{~cm}$ da superficie, necessita-se utilizar líquidos manométricos de densidades compatíveis. 


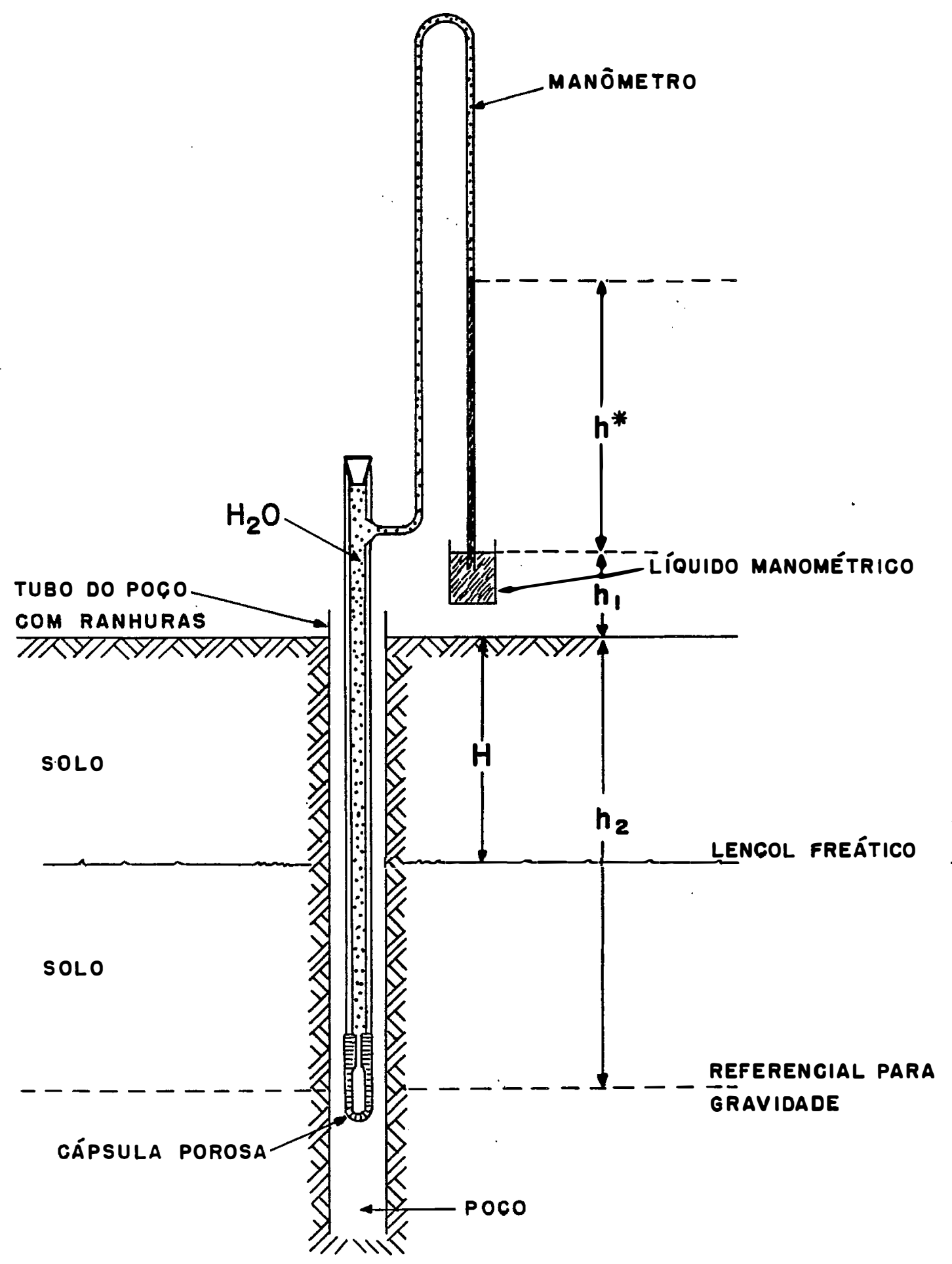

FIGURA 2 - Esquema de tensiômetro utilizado para monitoramento do lençol freático 


\subsection{Parcelas experimentais}

As parcelas experimentais, num total de vinte, foram locadas visando a coincidência com a maior elevação do lençol freático. Como a maioria das amostras de desenvolvimento da cultura era do tipo destrutivo, as dimensões das parcelas foram de $9,0 \mathrm{~m} \times 20,0 \mathrm{~m}$ reservando-se uma área central de 4,5×5,0m para análise da produção final.

\subsection{Cultivo}

O milho utilizado foi o híbrido simples ZEN-8568, de ciclo intermediário (130 dias), tipo de endosperma normal com coloração amarelo forte, tipo de grãos semidentado e porte médio da planta de $2,10 \mathrm{~m}$ e inserção da espiga à 1,20m. A produtividade média de onze locais deste material no Estado de São Paulo foi de $9492 \mathrm{~kg} \cdot \mathrm{ha}^{-1}$ de espigas e de $8143 \mathrm{~kg} \cdot \mathrm{ha}^{-1}$ de grãos (dados e sementes fornecidos pela empresa Zeneca Sementes Ltda). A escolha desta cultivar foi em função dos híbridos simples apresentarem grande homogeneidade das características fisiológicas entre plantas e de um bom desempenho em ensaios anteriores conduzidos pela Seção de Milho do IAC. 
As semeaduras foram realizadas manualmente e paralelas aos drenos subterrâneos nos dias 18 e 19 de outubro de 1994, com espaçamento de 0,90m entre linhas e $0,20 \mathrm{~m}$ entre plantas, colocando-se duas sementes por cova. As emergências das plantas ocorreram nos dias 25 e 26 de outubro. Aos 30 dias após a emergência (DAE) foi realizado um desbaste deixando apenas uma planta por cova, o que corresponde a uma população aproximada de 56.000 plantas por hectare.

A adubação básica foi realizada de acordo com a fertilidade do solo, e aplicada no sulco antes da semeadura, nas seguintes doses: $15 \mathrm{~kg} \cdot \mathrm{ha}^{-1}$ de $\mathrm{N}, 70 \mathrm{~kg} \cdot \mathrm{ha}^{-1}$ de $\mathrm{P}_{2} \mathrm{O}_{5}$ e $60 \mathrm{~kg} \cdot \mathrm{ha}^{-1}$ de $\mathrm{K}_{2} \mathrm{O}$. A adubação de cobertura foi de $80 \mathrm{~kg} \cdot \mathrm{ha}^{-1}$ de $\mathrm{N}$, realizada logo após o desbaste.

Para eliminar as plantas daninhas foi feita uma capina manual entre 7 a 14 DAE e uma aplicação de herbicida (Glamocil 50ml/20l $\mathrm{H}_{2} \mathrm{O}$ + espalhante) aos $16 \mathrm{DAE}$.

o combate à pragas foi feita através de duas pulverizações e um polvilhamento de inseticida ao longo do ciclo da cultura. As pulverizações foram com DECIS para controle da lagarta rosca (14 DAE) e pulgões (64 DAE). O polvilhamento visou $\circ$ controle da lagarta do cartucho (Spodoptera frugiperda) e ocorreu aos 28 e 29 DAE, com SEVIN-10. 
A colheita foi a 130 DAE, considerando-se como área útil para análise de produção, 5 linhas de 5,0m de comprimento das partes centrais das parcelas, ou seja, onde - lençol freático permaneceu mais elevado durante as precipitações pluviométricas.

\subsection{Crescimento da cultura}

Para a análise de crescimento das plantas cultivadas em área com 5 diferentes espaçamentos de drenos subterrâneos foram determinados os seguintes parâmetros biométricos e fisiológicos: altura da planta, porcentagem de recobrimento do solo, índice de área foliar, acúmulo de matéria seca, eficiência de conversão da matéria seca em grãos, taxa de crescimento da cultura e desenvolvimento efetivo do sistema radicular.

Para tanto, foram executadas medidas frequentes e sucessivas, em intervalos de tempo que variaram de 14 a 25 dias, da altura das plantas, da porcentagem de recobrimento do solo, da área foliar, do peso da matéria seca das diferentes partes aéreas e do sistema radicular da planta. As coletas das amostras foram realizadas aos 15, 30, 44, 59,84 e 100 DAE. 
A altura das plantas foi determinada medindo-se com uma trena, desde o solo até a altura média do dossel vegetativo até o lançamento do pendão, após a qual considerou-se como ponto de referência a inserção da última folha. A porcentagem de recobrimento do solo foi medida pelo método da intersecção de uma corda graduada de 0,10 em $0,10 \mathrm{~m}$ esticada transversalmente às linhas de cultivo até as plantas atingirem a altura de $1,50 \mathrm{~m}$ e depois, visualmente, através do grau de sombreamento do solo quando os raios do sol incidiam verticalmente sobre elas.

A área foliar e o acúmulo de matéria seca foram determinados colhendo-se as plantas existentes em 1,00m de linha de semeadura, com quatro repetições, representando assim $0,90 \mathrm{~m}^{2}$, tomada ao acaso. Após a colheita as plantas eram conduzidas ao laboratório, onde de cada parcela, determinavam-se a área foliar e os pesos da matéria seca das folhas, colmos, ráquis + brácteas e grãos.

\subsubsection{Indice de área foliar}

Inicialmente, estimou-se a área foliar (A.F.) de todas as plantas colhidas em cada parcela. Para isso, mediu-se, de cada folha, o comprimento (C) sobre a nervura 
principal, desde o ponto de inserção do limbo com a bainha até o ápice da folha e, também, na direção da maior largura (L), perpendicularmente à nervura principal. Aplicou-se, em seguida, a expressão (MCKEE, 1964):

$$
A \cdot F .=0,75 \sum_{I=1}^{n}(C i * I i)
$$

onde, $\mathrm{n}$ é o número total de folhas das plantas colhidas na parcela, em cada amostragem.

Posteriomente, essas medições foram facilitadas através do uso do aparelho integrador de área foliar (LI3000, da Li-Cor, Inc., EUA). O aparelho previamente calibrado, fornecia a área acumulada das folhas de cada planta.

Determinou-se o indice de área foliar (I.A.F.) de cada parcela por ocasião da amostragem, dividindo-se o valor medido da área foliar pelo espaço ocupado $\left(0,90 \mathrm{~m}^{2}\right)$.

\subsubsection{Partição da matéria seca}

$\mathrm{Na}$ determinação do peso da matéria seca total, fez-se a separação das diversas partes da planta (folhas, colmo, ráquis + brácteas e grãos) acondicionando-as em 
sacos de papel perfurados e colocando-os em estufas de circulação forçada de ar a $60-65^{\circ} \mathrm{C}$, até peso constante.

Os valores obtidos por pesagem foram convertidos em peso de matéria seca por unidade de área $\left(g \cdot \mathrm{m}^{-2}\right)$.

\subsubsection{Taxa de crescimento da cultura}

A taxa de crescimento da cultura (T.C.C.), em g.dia ${ }^{-1}$, foi obtida segundo a expressão (RADFORD, 1967):

$$
\text { T.C.C. }=\left(W_{2}-W_{1}\right) /\left(t_{2}-t_{1}\right)
$$

onde, $W_{1}$ e $W_{2}$ são, respectivamente, o peso médio da matéria seca nos tempos $t_{1}$ e $t_{2}$.

\subsubsection{Eficiência na conversão de matéria seca em grãos}

Foram determinadas as relações entre o peso da matéria seca dos grãos e o peso da matéria seca de algumas partes da planta, ou seja, a eficiência da conversão da matéria seca em grãos. 
a. Peso mat.seca dos grãos /. Peso mat.seca total;

b. Peso mat.seca dos grãos / Peso mat.seca das espigas;

c. Peso mat.seca dos grãos / Peso mat.seca(folhas + colmos) Em cada coleta de dados, foram realizadas as 'análises de variância para testar as significâncias do índice de área foliar, do peso da matéria seca e da eficiência na conversão de matéria seca em grãos, entre os 5 tṛatamentos.

\subsubsection{Resistência estomática à difusão de vapor d'água}

A resistência estomática foi medida através de um porômetro de equilíbrio dinâmico (LI-1600 steady-state porometer), nos estádios de florescimento e de enchimento dos grãos.

o resultado da resistência estomática foi obtida diretamente, medindo-se a taxa de transpiração da folha dentro de uma mini câmara. Essas medidas foram feitas no limbo da terceira folha a partir do ápice da planta, em ambas as superfícies. Para garantir a representatividade dos dados, as medidas foram realizadas em dez plantas, tomadas ao acaso, por ocasião de cada medição. 


\subsubsection{Profundidade efetiva do sistema radicular}

Concomitantemente às tomadas de medidas e amostragens de plantas realizou-se a coleta sistemática do sistema radicular do milho, segundo a metodologia de Gottingen e adaptada por FUJIWARA et al. (1994).

As amostras foram coletadas a $0,10-0,17 \mathrm{~m}$ da linha de semeadura e tomadas de 0,10 em $0,10 \mathrm{~m}$ até a profundidade de $0,70 \mathrm{~m}$. Nessas amostras foram adicionadas uma solução de 5\% de álcool para conservação e auxílio na dispersão dos torrões para separação das raízes na lavagem. Após, essa operação em água corrente e peneira de malha de 0,1 mm, as raízes foram separadas manualmente de outros materiais orgânicos e secas em estufa a $60^{\circ} \mathrm{C}$. Determinou-se - peso em balança analítica e estimou-se a densidade de comprimento das raízes pelo método da interseção de linhas (TENNANT, 1975) .

Considerou-se como a profundidade efetiva do sistema radicular aquela em que concentravam 90\% das raízes, através de interpolações entre a somatória dos valores de duas profundidades consecutivas. 


\title{
3.8. Análise de produção
}

\begin{abstract}
Após a maturação fisiológica das plantas, foi colhida, de cada parcela, a produção de grãos, e os resultados convertidos em $\mathrm{kg} \cdot \mathrm{ha}^{-1}$.

Para a padronização da umidade entre os tratamentos, inicialmente, determinou-se a umidade de cada parcela, em porcentagem, através da expressão:
\end{abstract}

$$
\mathrm{U} \%=100(\mathrm{P}-\mathrm{p}) / \mathrm{P}
$$

onde: P é o peso úmido de uma amostra dos grãos ( $g$ ) ;

p é o seu peso bruto final (g) após secagem em estufa a $105^{\circ} \mathrm{C}$.

Assim, pode-se padronizar os dados de produção para mesma umidade, através da expressão:

$$
\mathrm{PC}=\mathrm{Pi}(100-\mathrm{U} \%) / 100-\mathrm{Ud} \%
$$

onde: Pc é a produção corrigida (kg.ha-1);

Pi é a produção inicial (kg.ha-1);

U⿳ é a umidade determinada na amostra;

Ud\% é a umidade desejada, no caso, de 13\%. 


\section{RESUltados e Discussão}

\subsection{Nível do lençol freático}

A recarga do lençol freático foi promovida exclusivamente por precipitações naturais. No entanto, devido a localização da área experimental ser em um "polder", e acima desta, a existência de uma bacia de contribuição de aproximadamente 250 ha, as flutuações do nível freático foram dependentes também de fatores externos, como por exemplo, da capacidade de escoamento das moto-bombas quando a cota do rio Jacupiranga estava acima do nível interno do polder, do represamento da água nas valas para facilidade na irrigação por inundação nos tabuleiros de arroz, entre outros.

Durante o ciclo da cultura, as precipitações pluviométricas acumuladas atingiram 917,0 mm, com totais mensais variando de $96,0 \mathrm{~mm}$ (fase de desenvolvimento vegetativo) a $313,8 \mathrm{~mm}$ (fase de enchimento dos grãos) . 
A Figura 3 mostra a distribuição das precipitações ocorridas durante o ciclo da cultura e o comportamento do lençol freático na posição central entre dois drenos subterrâneos de cada um dos tratamentos.

(A)
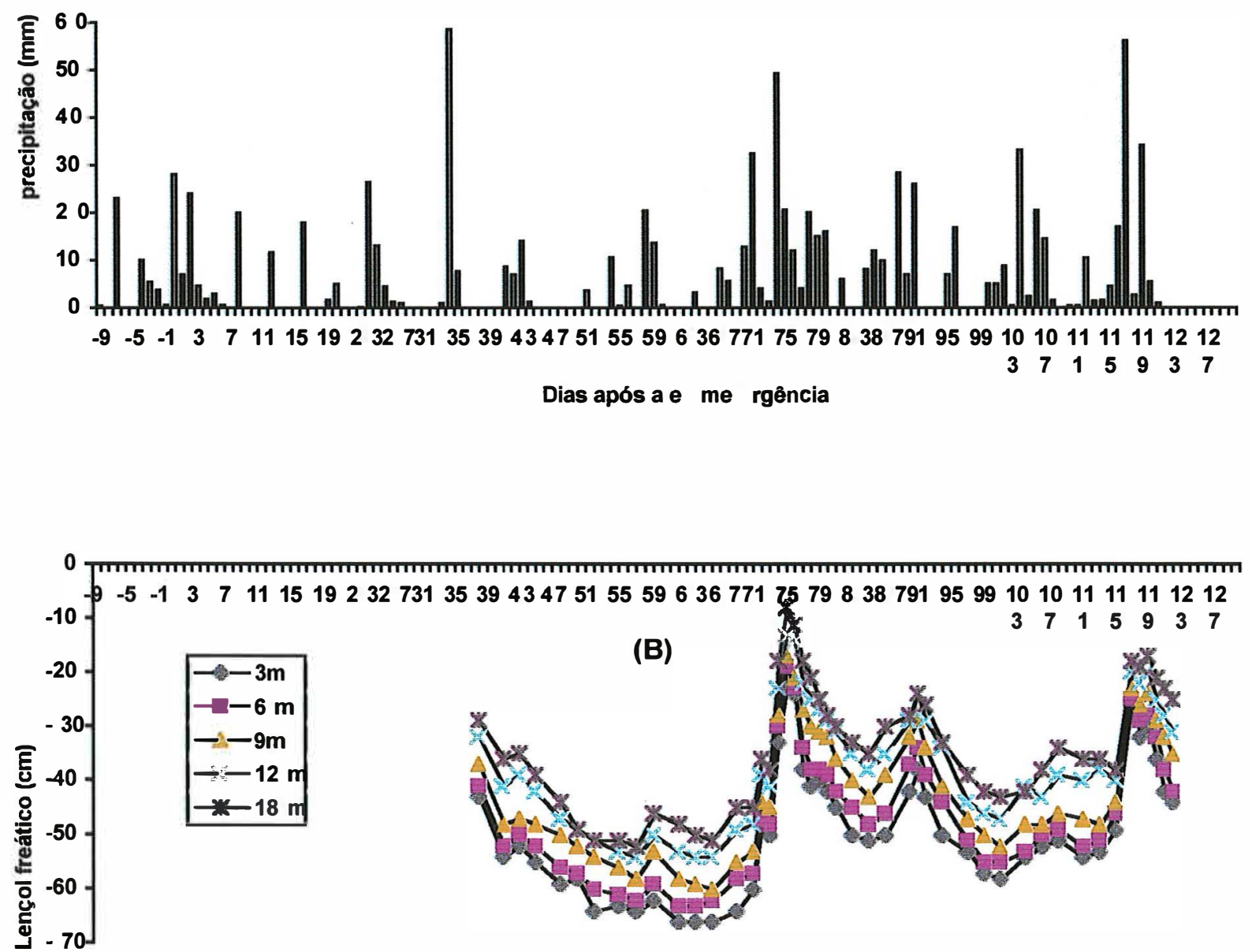

FIGURA 3- Distribuição das precipitações no ciclo da cultura (A) e nível do lençol freático nos tratamentos de drenagem subterrânea (B), Pariquera Açu, 94/95. 


\subsubsection{Determinação do lençol freático: Método do poço vs Método Proposto}

Os resultados do nível freático medidos diretamente nos poços de observações e os determinados pelo método do tensiômetro apresentaram-se semelhantes, Tabela 4. A equação de regressão linear obtida entre ambos os métodos foi a seguinte:

$$
Y=1,512419+0,9747942 * X \quad(r=0,99 * *, n=133)
$$

onde, $Y$ é a leitura observada no poço e $\mathrm{X}$ a determinada pelo tensiômetro, ambas em $\mathrm{cm}$.

A análise mostrou-se altamente significativa e correlacionada, com inclinação muito próxima de $1: 1$, embora, com um pequeno deslocamento do coeficiente linear da reta, isto é, quando a determinação no poço é zero, corresponde a uma leitura de $1,5 \mathrm{~cm}$ para $\circ$ tensiômetro. Isso indica um pequeno erro apenas para leituras mais superficiais.

Portanto, em condições de várzea, onde lençol freático flutua da superfície até $1,0 \mathrm{~m}$ de profundidade, pode-se substituir com vantagens, a metodologia convencional pela proposta no trabalho. Uma das vantagens que se pode atribuir ao tensiômetro de manômetro com 
líquido de densidade pouco superior a da água, é a visualização instantânea do comportamento geral de escoamento da área, através da drenagem subterrânea. Uma vez que pode-se colocar uma série de tensiômetros entre os drenos e feitas as leituras em um único manômetro.

Outra vantagem operacional importante, no acompanhamento diário, é a facilidade e rapidez nas leituras, onde o operador não necessita de nenhum material além da prancha de anotação. 


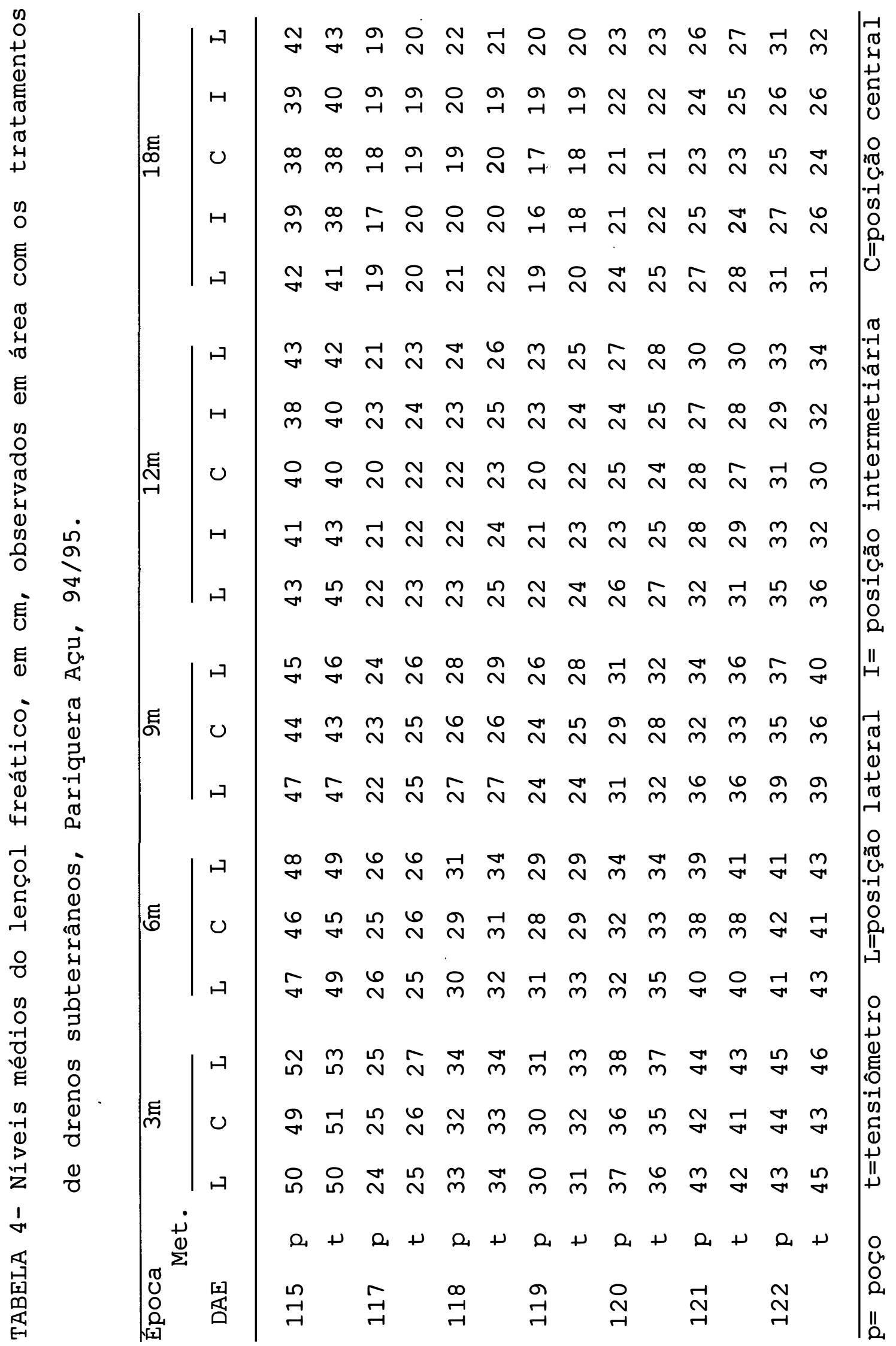




\subsection{Crescimento da cultura}

\subsubsection{Altura e recobrimento do solo pelas plantas}

Através das Tabelas 5 e 6 , observam-se em todas as fases de desenvolvimento da cultura após a emergência, que não houveram diferenças significativas entre os tratamentos de drenagem subterrânea para altura das plantas e a porcentagem de cobertura vegetal no solo. No presente experimento, embora tivesse ocorrido aos 35-36 DAE uma precipitação de $58,5 \mathrm{~mm}$, esta não foi suficientemente elevada para provocar sintomas de injúrias às plantas ou que refletissem nesses parâmetros, provavelmente, por que nos dias anteriores e subsequentes não ocorreram precipitações elevadas. Resultados semelhantes foram obtidos por COSTA (1994). No entanto, CRUCIANI (1981) apresentam resultados divergentes, indicando suceptibilidade da altura da planta a qualquer grau de encharcamento.

Aos $59 \mathrm{DAE}$, com as plantas alcançando o seu pleno desenvolvimento em altura, a cobertura do solo apresentavase total. A partir daí, mesmo em condições inadequadas em algum momento da fase reprodutiva, elas mantiveram-se aparentemente, vigorosas. 
TABELA 5 - Altura média e seu respectivo erro padrão de plantas de milho cultivado em área com cinco espaçamentos de drenos subterrâneos. Pariquera Açu, 94/95, média de 20 determinações.

\begin{tabular}{|c|c|c|c|c|c|c|}
\hline \multirow{2}{*}{$\begin{array}{l}\text { Trata- } \\
\text { mento }\end{array}$} & \multicolumn{6}{|c|}{ DAE } \\
\hline & $15 *$ & 30 & 44 & 59 & 84 & 100 \\
\hline & $\ldots \ldots$ & $\ldots \ldots$ & $\cdots \ldots$ & $m \ldots$ & $\cdots \ldots$ & $\ldots \ldots$ \\
\hline $3 m$ & $21 \pm 3$ & $62 \pm 4$ & $179 \pm 3$ & $228 \pm 2$ & $232 \pm 4$ & $230 \pm$ \\
\hline $6 m$ & $20 \pm 4$ & $62 \pm 6$ & $176 \pm 3$ & $225 \pm 3$ & $229 \pm 2$ & $228 \pm$ \\
\hline $9 m$ & $24 \pm 4$ & $65 \pm 5$ & $178 \pm 2$ & $228 \pm 2$ & $226 \pm 3$ & $228 \pm$ \\
\hline $12 m$ & $26 \pm 5$ & $69 \pm 6$ & $180 \pm 2$ & $229 \pm 3$ & $229 \pm 3$ & $229 \pm$ \\
\hline $18 \mathrm{~m}$ & $22 \pm 4$ & $63 \pm 6$ & $176 \pm 3$ & $228 \pm 7$ & $230 \pm 3$ & $227 \pm$ \\
\hline
\end{tabular}


TABELA 6- Porcentagem de recobrimento do solo pelas plantas de milho e seu respectivo erro padrão da média obtidos em áreas com cinco espaçamentos de drenos subterrâneos, Pariquera Açú, 94/95, média de 20 determinações.

\begin{tabular}{lcccccc}
\hline $\begin{array}{l}\text { Trata- } \\
\text { mento }\end{array}$ & $15^{*}$ & 30 & 44 & 59 & 84 & 100 \\
\cline { 2 - 6 } & $13 \pm 1$ & $25 \pm 2$ & $94 \pm 2$ & $99 \pm 1$ & $99 \pm 1$ & $88 \pm 1$ \\
$3 \mathrm{~m}$ & $11 \pm 1$ & $26 \pm 2$ & $92+1$ & $99 \pm 1$ & $98 \pm 1$ & $88 \pm 2$ \\
$6 \mathrm{~m}$ & $12 \pm 1$ & $27 \pm 2$ & $93 \pm 1$ & $99 \pm 1$ & $97 \pm 2$ & $86 \pm 3$ \\
$9 \mathrm{~m}$ & $13 \pm 1$ & $28 \pm 2$ & $93 \pm 3$ & $99 \pm 1$ & $99 \pm 1$ & $87 \pm 4$ \\
$12 \mathrm{~m}$ & $12 \pm 1$ & $25 \pm 2$ & $93 \pm 2$ & $99 \pm 1$ & $98 \pm 1$ & $85 \pm 3$ \\
$18 \mathrm{~m}$ & $85 \pm 2 \pm 1$
\end{tabular}

$15 \mathrm{DAE}=8.11 .1994$

\subsubsection{Indice de área foliar}

Verifica-se através da Tabela 7 que, assim como para o crescimento da planta (altura) e à \% de recobrimento do solo, não houve diferenças significativas entre os tratamentos extremos até os 100 DAE. No entanto, para os outros, nas amostragens de 44 e 59 DAE mostraram-se menos 
desenvolvidas; provavelmente, em virtude do número pequeno de repetições e da variabilidade entre elas, e não devido ao efeito da umidade do solo.

Através da Figura 4, o índice de área foliar em função da idade, verifica-se que os IAF de todos os tratamentos foram crescentes da emergência até cerca de 60 DAE, para depois decrescerem. Este comportamento, aumento do IAF até um valor máximo no florescimento passando a declinar no período de enchimento dos grãos é típico da cultura do milho, conforme observou TOLLENAAR (1977), entre outros. 


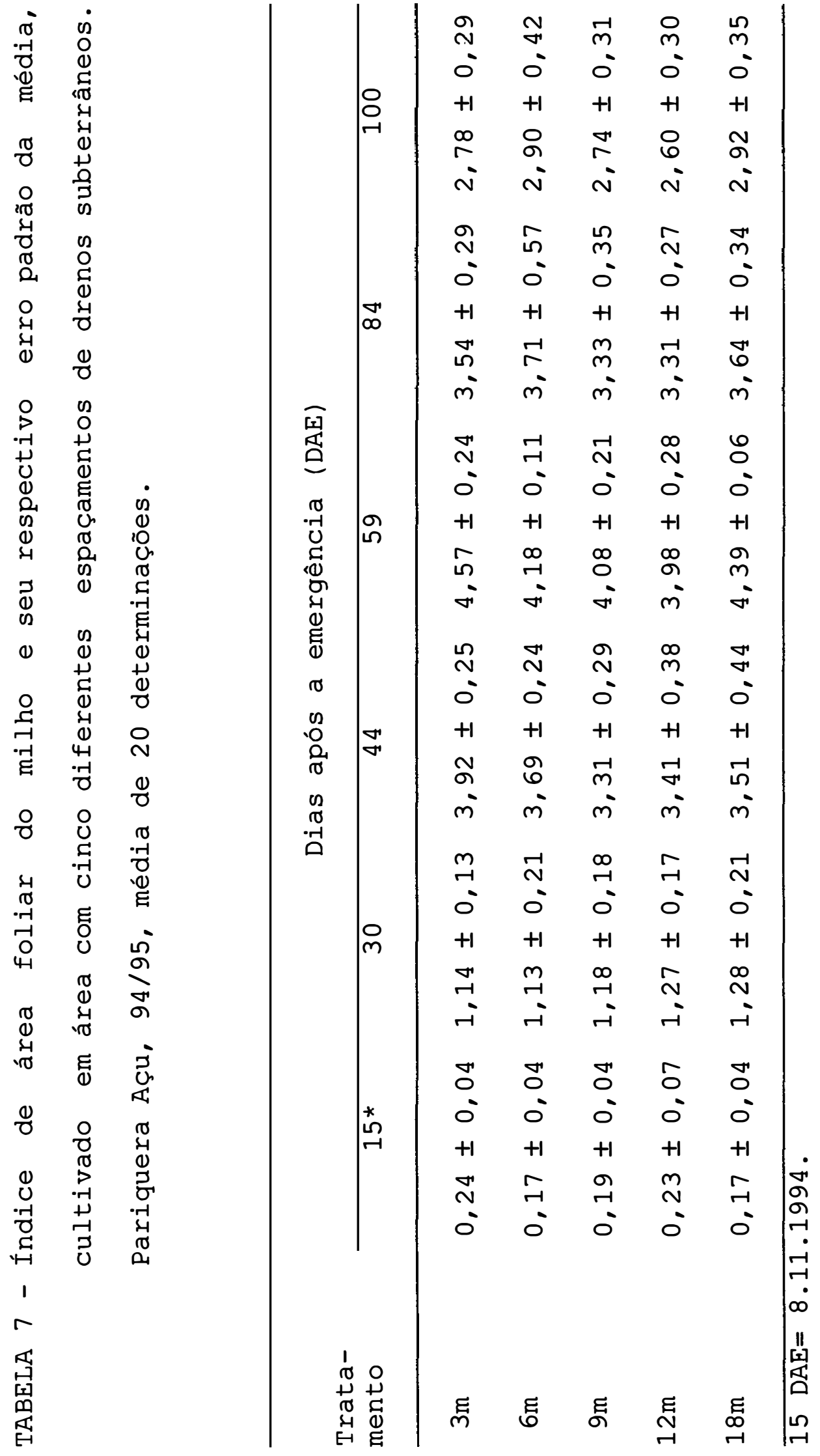




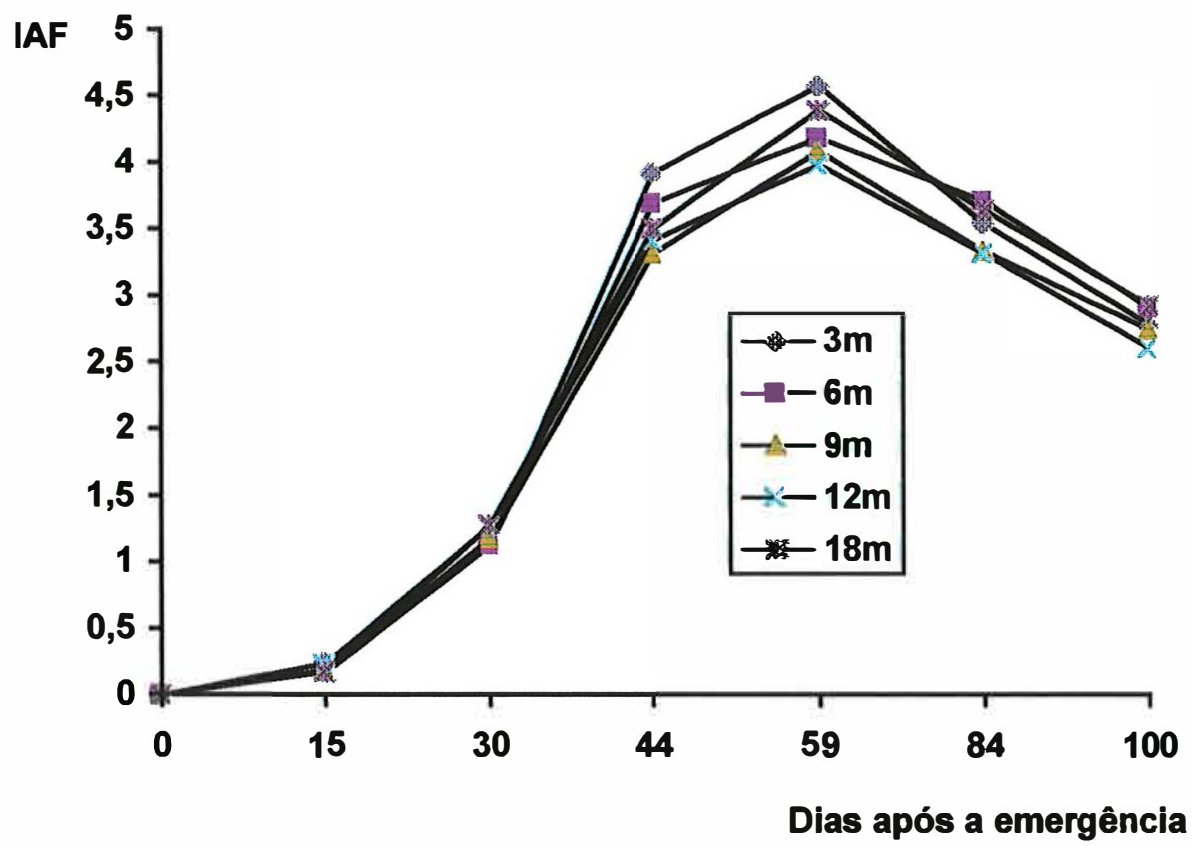

FIGURA 4 - Índice de área foliar (IAF) do milho cultivado em várzea sistematizada com cinco espaçamentos de drenos subterrâneos, Pariquera Açu, 94/95. 


\subsubsection{Acúmulo da matéria seca}

\subsubsection{Folha}

Através do Tabela 8, verifica-se que desde a emergência até a fase final de enchimento dos grãos não ocorreram diferenças significativas entre os tratamentos quanto ao peso da matéria seca das folhas. Esse comportamento é similar ao que fora constatado no índice de área foliar, mostrando uma possível correlação entre ambas. Portanto, provavelmente, os estresses impostos pelos tratamentos não foram sucientemente altos para a diferenciação na absorção e assimilação dos nutrientes pelas plantas, e na manutenção da integridade da fonte de energia.

\subsubsection{Colmo}

Através da Tabela 9, observa-se que após a emergência até o final do fase de enchimento dos grãos não houve diferenciação entre os tratamentos para o peso médio da matéria seca de colmos por unidade de área de terreno. 


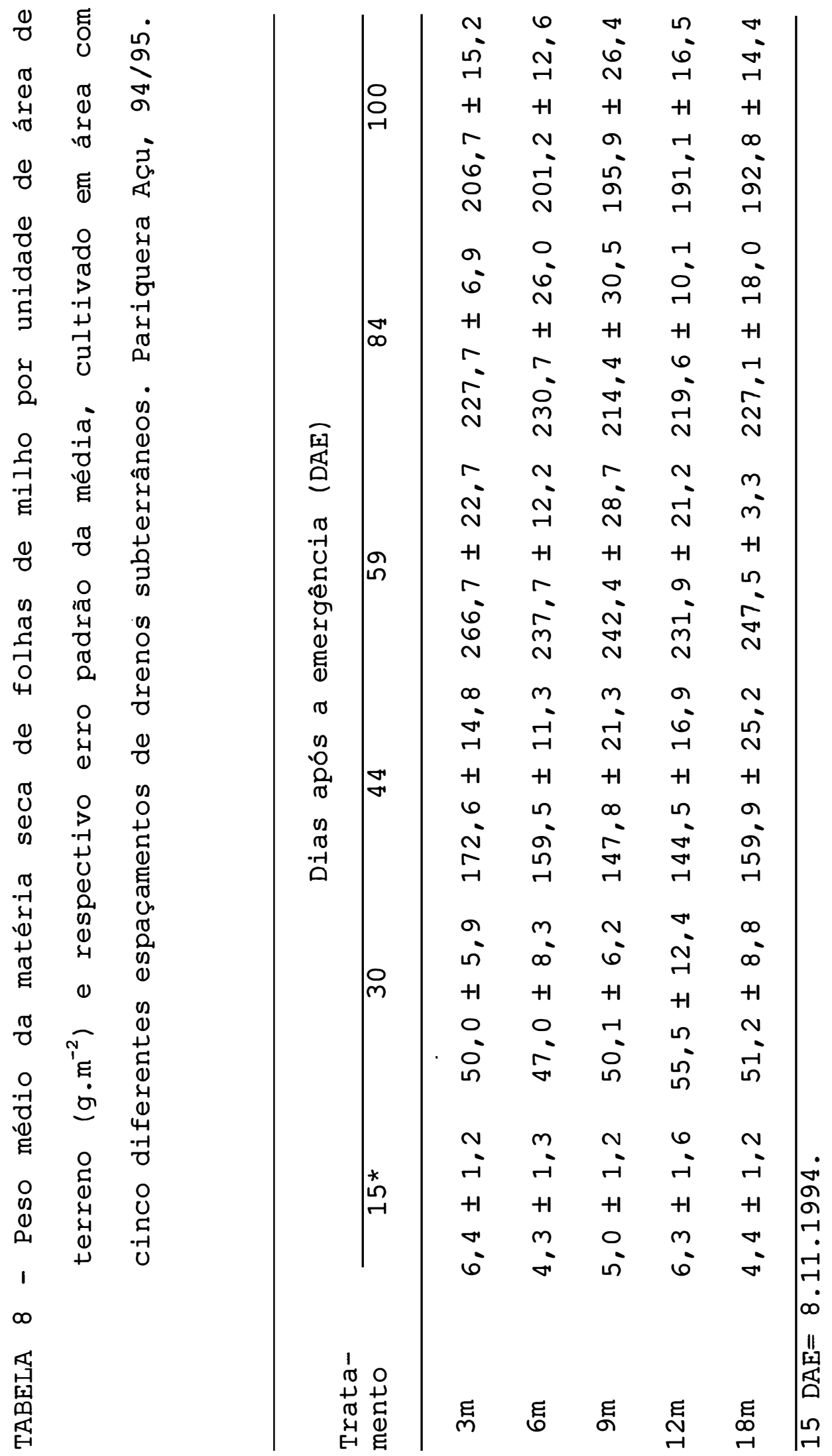




\subsubsection{Brácteas, Ráquis e Grãos}

Os resultados obtidos no acúmulo de matéria seca nas brácteas + ráquis e grãos são apresentados nas Tabelas 10 e 11, respectivamente.

Nota-se pela Tabela 10 que aos $59 \mathrm{DAE}$, época em que iniciava o crescimento das espigas, os pesos de brácteas + ráquis não apresentavam diferenças estatísticas entre os tratamentos. Aos 84 DAE os tratamentos melhores drenados $(3 \mathrm{~m}$ e $6 \mathrm{~m})$ desenvolveram menor peso que outros tratamentos, no entanto, eles continuaram a desenvolver até a amostragem do 100 DAE, ultrapassando-os. Isso deve ter ocorrido em função da maior ou menor disponibilidade hídrica e do nível de estresse imposto pelo encharcamento (Figura 3).

Através da Tabela 11, verifica-se o mesmo
comportamento no desenvolvimento dos grãos, ou seja,
inicialmente, os tratamentos com drenagem menos intensa
desenvolveram maior peso, sendo, posteriormente
ultrapassados pelos tratamentos mais drenados.




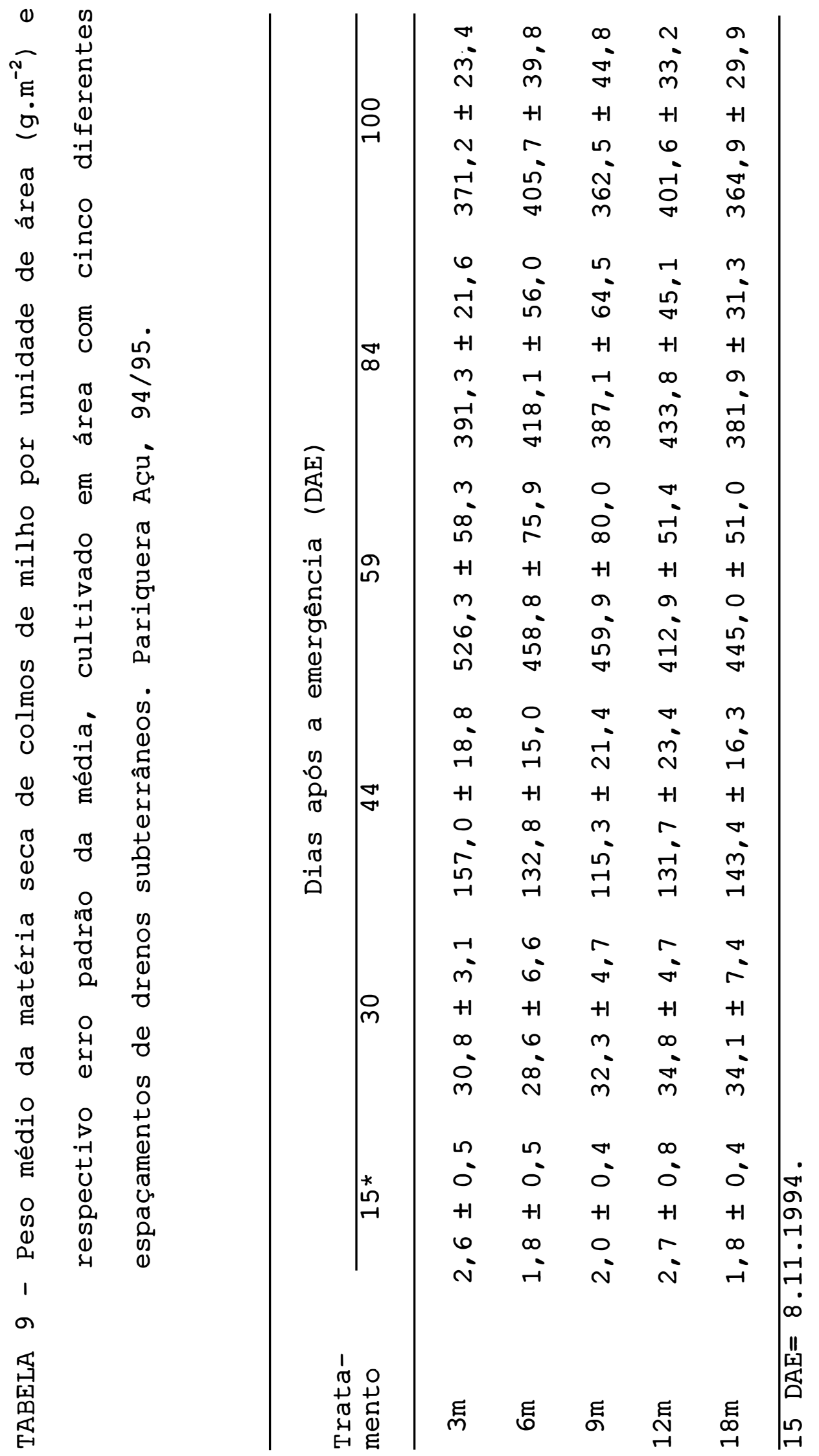


TABELA 10- Peso médio da matéria seca de brácteas + ráquis de milho por unidade de área $\left(\mathrm{g} \cdot \mathrm{m}^{-2}\right)$ e respectivo erro padrão da média, cultivado em área com cinco espaçamentos de drenos subterrâneos. Pariquera Açu, $94 / 95$.

\begin{tabular}{lcccc}
\hline \multicolumn{5}{c}{ Dias após a emergência (DAE) } \\
$\begin{array}{l}\text { Trata } \\
\text { mento }\end{array}$ & $59 *$ & 84 & 100 & 130 \\
\hline $3 \mathrm{~m}$ & $18,2 \pm 4,7$ & $267,3 \pm 16,5$ & $364,4 \pm 13,8$ & $336,0 \pm 17,7$ \\
$6 \mathrm{~m}$ & $14,9 \pm 4,7$ & $205,9 \pm 25,7$ & $372,8 \pm 16,0$ & $335,8 \pm 15,9$ \\
$9 \mathrm{~m}$ & $18,5 \pm 4,7$ & $296,9 \pm 14,1$ & $313,7 \pm 14,4$ & $283,0 \pm 16,4$ \\
$12 \mathrm{~m}$ & $16,9 \pm 2,8$ & $325,1 \pm 24,2$ & $323,0 \pm 14,8$ & $299,0 \pm 18,6$ \\
$18 \mathrm{~m}$ & $17,5 \pm 4,0$ & $314,9 \pm 15,9$ & $304,2 \pm 33,3$ & $295,2 \pm 21,8$ \\
\hline $59 \mathrm{DAE}=22.12 .1994$ & & & & \\
\hline
\end{tabular}


TABELA 11- Peso médio da matéria seca de grãos de milho por unidade de área $\left(\mathrm{g} \cdot \mathrm{m}^{-2}\right)$ e respectivo erro padrão da média, cultivado em área com cinco espaçamentos de drenos subterrâneos. Pariquera Açu, 94/95.

\begin{tabular}{|c|c|c|c|}
\hline \multirow{2}{*}{ Tratamento } & Dias & pós a emergência & \multirow{2}{*}{$\frac{(\mathrm{DAE})}{130}$} \\
\hline & $84^{\star}$ & 100 & \\
\hline $3 m$ & $370,9 \pm 56,5$ & $694,3 \pm 29,6$ & $730,7 \pm 13,3$ \\
\hline $6 m$ & $282,1 \pm 35,9$ & $661,9 \pm 42,1$ & $683,3 \pm 22,2$ \\
\hline $9 m$ & $399,8 \pm 25,4$ & $638,0 \pm 27,0$ & $671,3 \pm 24,6$ \\
\hline $12 \mathrm{~m}$ & $397,3 \pm 23,9$ & $621,3 \pm 36,7$ & $665,4 \pm 29,7$ \\
\hline $18 \mathrm{~m}$ & $436,2 \pm 41,1$ & $632,8 \pm 33,9$ & $652,6 \pm 19,1$ \\
\hline
\end{tabular}

\subsubsection{Peso da materia seca total}

Os resultados obtidos no acúmulo de matéria seca total são apresentados na Tabela 12 .

Através da Tabela 12, contrariamente aos resultados obtidos por GOINS et al. (1966), KANWAR et al. (1988), entre outros, nota-se que durante todo o ciclo não houve diferença significativas entre os tratamentos para o peso da matéria seca total, indicando que o número de 
amostragens e repetições não foram suficientes para expressar significância estatística nas diferenças ocorridas, visíveis na Figura 5.

Os acúmulos de matéria seca total, típica curva de crescimento, com uma longa fase linear, representados na Figura 5, mostram que as produções biológicas máximas foram de 1636,$6 ; 1647,6 ; 1510,0 ; 1540,9$ e $1504,7 \mathrm{~g} \cdot \mathrm{m}^{-2}$ para os tratamentos $3 \mathrm{~m}, 6 \mathrm{~m}, 9 \mathrm{~m}, 12 \mathrm{~m}$ e $18 \mathrm{~m}$, respectivamente.

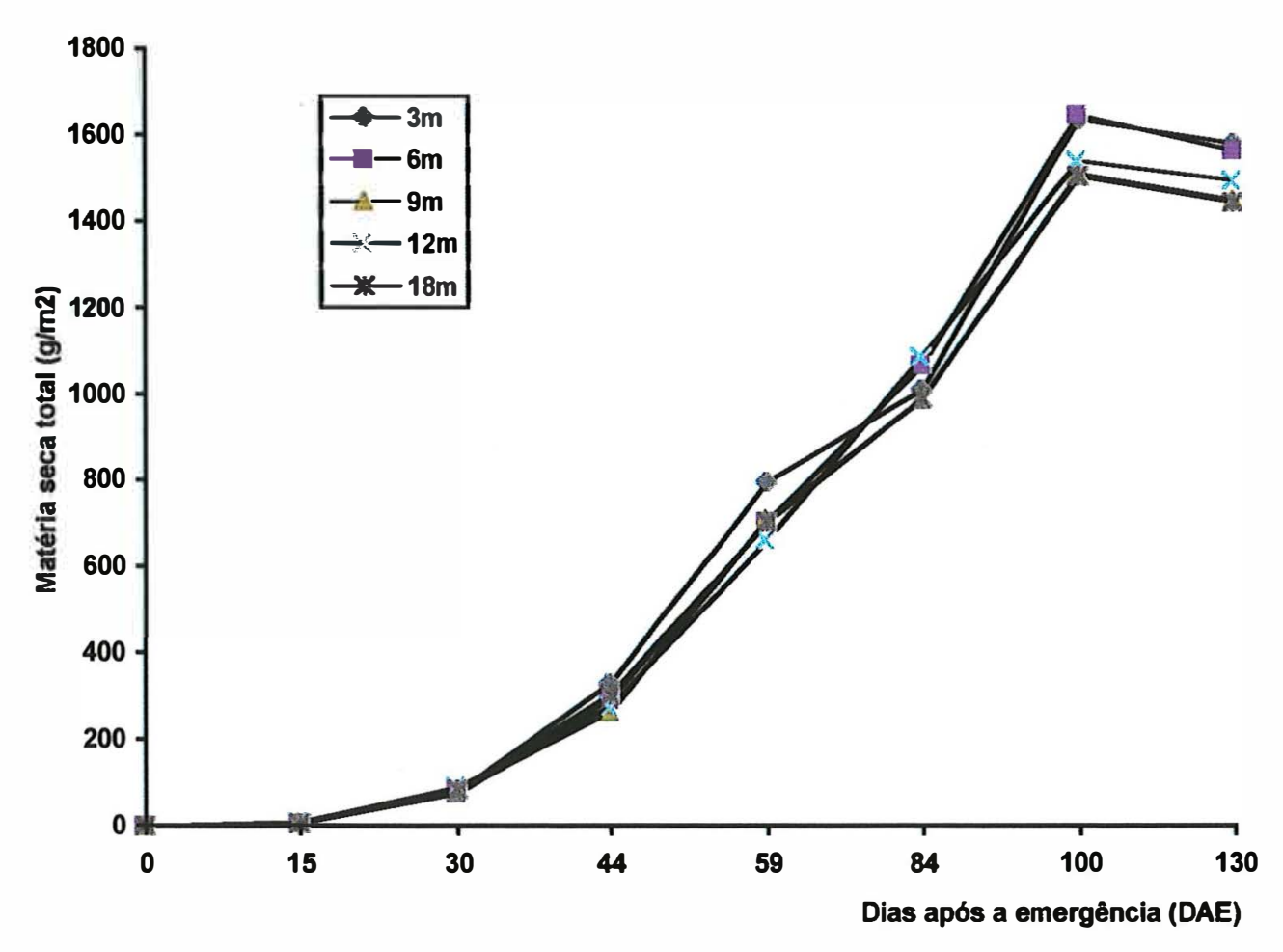

FIGURA 5 - Acúmulo de matéria seca total do milho, cultivado sob cinco condições diferentes de drenagem. Pariquera Açu, 94/95. 


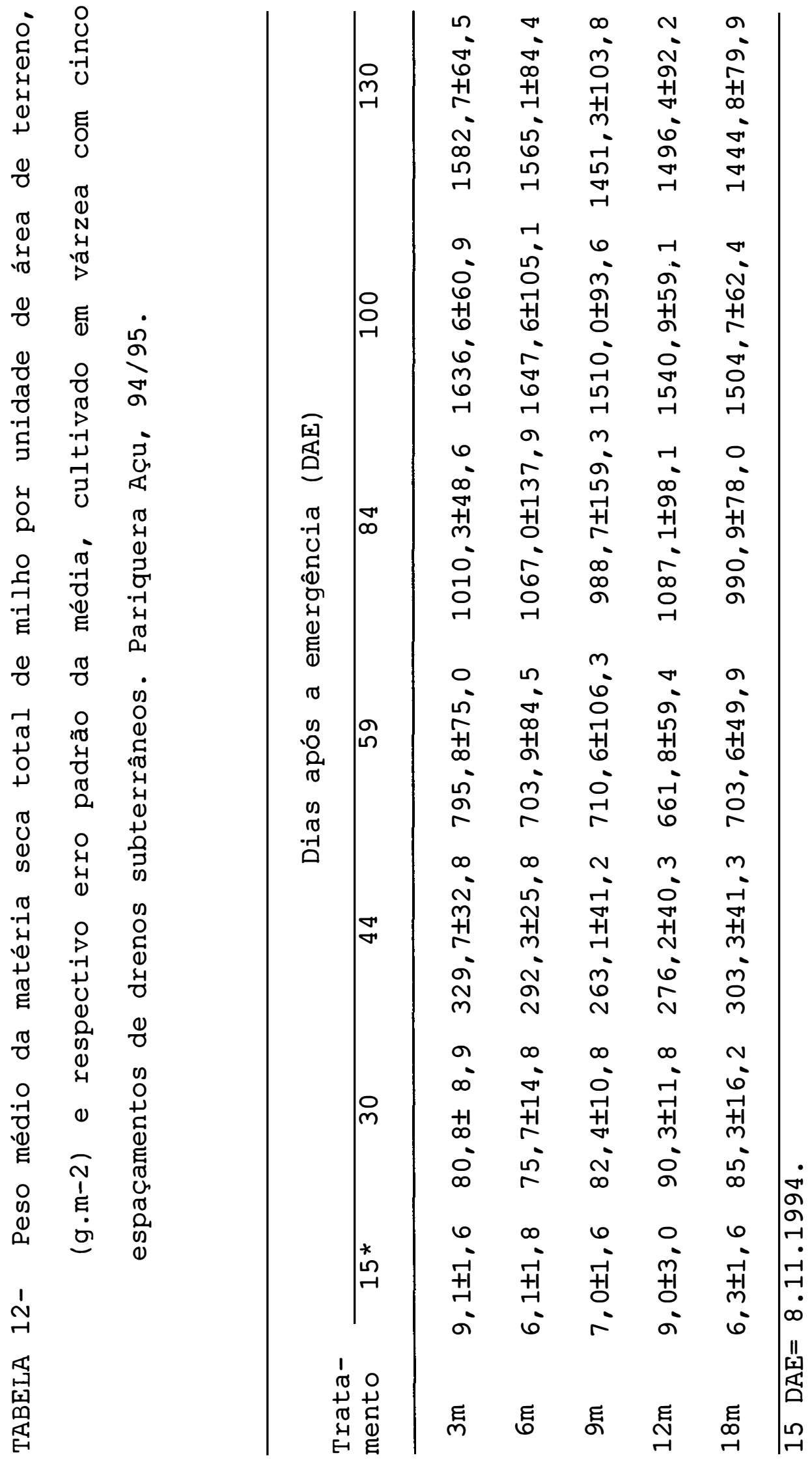


A Tabela 13 apresenta as regressões polinomiais obtidas para o acúmulo da matéria seca total com seus respectivos coeficientes de correlação nos tratamentos de drenagem subterrânea em Pariquera Açu.

Tabela 13- Equações polinomiais que ajustam $\circ$ acúmulo de matéria seca total nos tratamentos estudados de espaçamento de drenos em Pariquera Açu, 94/95.

Tratamento

\begin{tabular}{ccc}
\hline $3 m$ & $Y=56,428-11,079 x+0,516 x^{2}-0,0026 x^{3}$ & $0,985 * \star$ \\
$6 m$ & $Y=169,808-19,857 x+0,661 x^{2}-0,0033 x^{3}$ & $0,991 * \star$ \\
$9 m$ & $Y=110,329-14,887 x+0,559 x^{2}-0,0028 x^{3}$ & $0,990 * \star$ \\
$12 m$ & $Y=166,891-19,042 x+0,637 x^{2}-0,0032 x^{3}$ & $0,996 * *$ \\
$18 m$ & $Y=81,984-12,563 X+0,522 x^{2}-0,0026 x^{3}$ & $0,991 * \star$ \\
\hline$X=D A E$ & $Y=$ quantidade de matéria seca $\left(\mathrm{g} / \mathrm{m}^{2}\right)$ &
\end{tabular}

o modelo de regressão que melhor representou a relação entre peso da matéria seca total (g.m-2) e DAE foi a equação cúbica. Tal fato é concordante com ULLOA et al. (1982) e BASSOI (1990). A queda no acúmulo de matéria seca no final do ciclo deve-se, principalmente à queda de folhas senescentes e sua rápida decomposição no ambiente. 
A distribuição da matéria seca na planta em termos porcentuais é apresentada na Figura 6. Os resultados foram semelhantes aos obtidos por Keplin para plantio realizado em outubro e apresentados por SÁ (1993) e mostraram-se pouco afetados pelos tratamentos de espaçamento de drenos ou excesso e déficit de água ao longo de todo o ciclo da cultura. Esse fato tem sido observado por outros autores. PENNING de VRIES et al. (1989), relatam que há pouca sensibilidade na distribuição da matéria seca em relação ao ambiente para plantas de crescimento determinado.

A partição da matéria seca da planta (Figura 6) em nada contribuiu para explicar as diferenças na produção final da cultura impostas pelos tratamentos. 

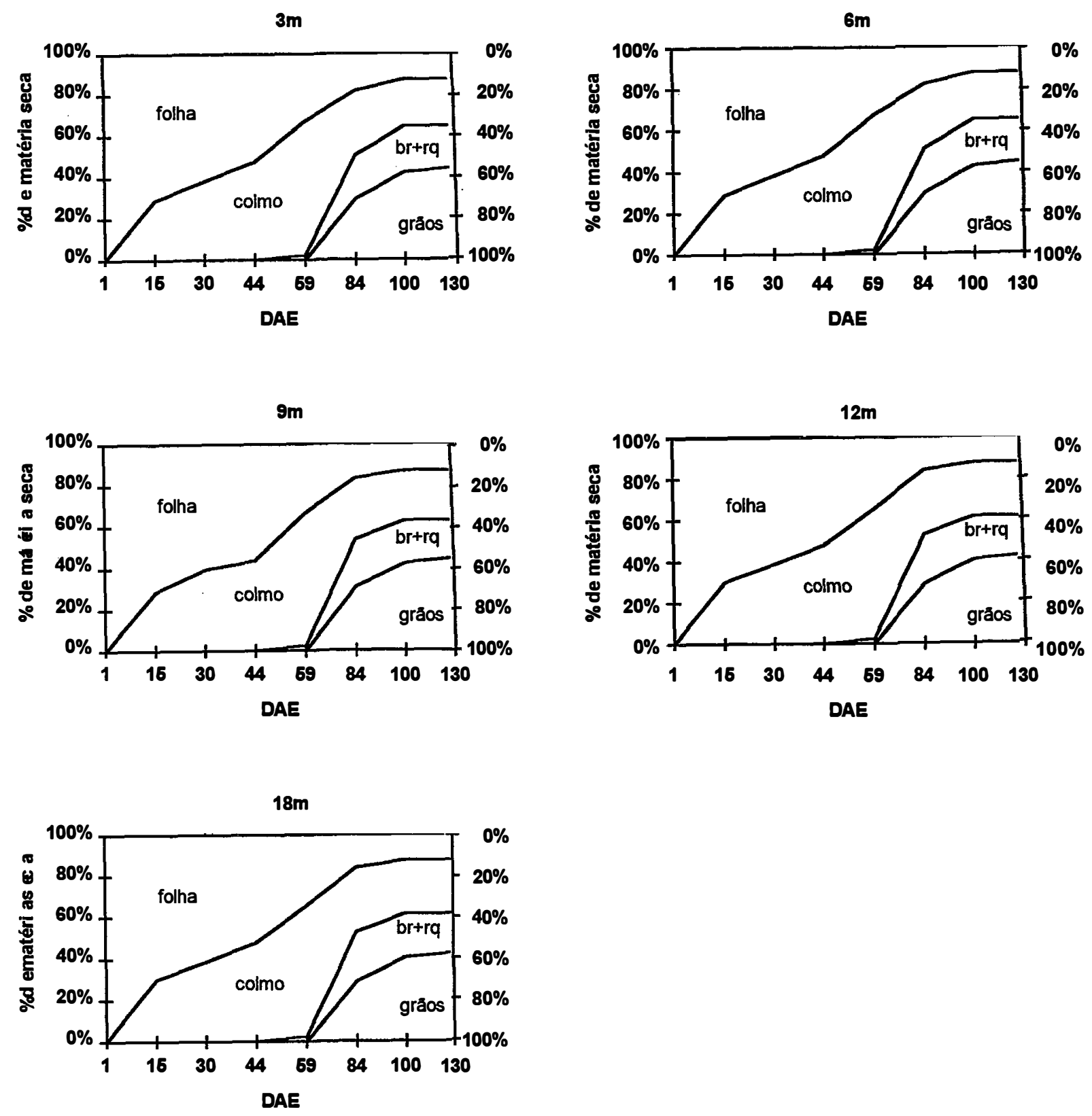

FIGURA 6- Porcentagem de acúmulo da matéria seca nos componentes da planta de milho cultivada em várzea sistematizada com cinco espaçamentos de drenos subterrâneos, Pariquera Açu, 94/95. 
A taxa de crescimento da cultura (T.C.C.), expressa em peso da matéria seca total (produção biológica) produzida por unidade de superfície de terreno e por unidade de tempo $\left(\mathrm{g} \cdot \mathrm{m}^{-2} \cdot \mathrm{dia}^{-1}\right)$, Figura 7 , foi pequena no início, em razão do pequeno valor do índice de área foliar. Com o desenvolvimento da planta a T.C.C. aumentou, em razão do maior aproveitamento da energia solar. No entanto, a T.C.C. que deveria apresentar a sua máxima expressão no florescimento, decresceu nesse período. A razão dessa queda pode ser explicada pela baixa incidência de luminosidade no período, como pode ser verificada na Tabela 14.

Já na fase de enchimento dos grãos, mesmo com baixa luminosidade, a T.C.C. aumentou, alcançando o máximo aos $100 \mathrm{DAE}$, para depois, decrescer rapidamente.

Foram calculadas as T.C.C. máxia média, ocorrida na fase linear de crescimento da cultura (44 a 100 DAE), por meio de regressão linear. As equações foram todas altamente significativas, com coeficientes de correlação variando entre 0,965 a 0,995 e reduziram possíveis problemas de amostragem de planta. Os resultados obtidos foram: 20,$9 ; 22,6 ; 20,4 ; 21,7$ e $19,8 \quad \mathrm{~g} \cdot \mathrm{cm}^{-2} \cdot \mathrm{dia}^{-1}$, respectivamente para os tratamentos $3 \mathrm{~m}, 6 \mathrm{~m}, 9 \mathrm{~m}, 12 \mathrm{~m}$ e $18 \mathrm{~m}$. Esses resultados mostraram-se muito próximos entre eles e sem padrão definido em relação aos tratamentos. 
Medições realizadas com o porômetro de equilíbrio dinâmico, às 14 horas em folhas maturas $\left(3^{\text {a }}\right.$ folha) e bem iluminadas, nos estádios do florescimento e do enchimento de grãos, mostraram que os estômatos das folhas, em todos os tratamentos apresentavam-se abertos e com taxas de transpiração semelhantes. As medições em 59 DAE resultaram nos seguintes valores de resistências estomáticas abaxial e adaxial: 0,98 e 2,0 s. $\mathrm{cm}^{-1} ; 1,13$ e 2,13 s. $\mathrm{cm}^{-1} ; 0,91$ e 1,44 $\mathrm{s} . \mathrm{cm}^{-1} ; 1,0$ e $1,54 \mathrm{~s} . \mathrm{cm}^{-1} ; 1,18$ e $1,89 \mathrm{s.cm}$, respectivamente para os tratamentos $3 \mathrm{~m}, 6 \mathrm{~m}, 9 \mathrm{~m}, 12 \mathrm{~m}$ e $18 \mathrm{~m}$. $\mathrm{Em} 84$ DAE foram: 0,98 e 2,66 s.cm $\mathrm{cm}^{-1} 1,09$ e $3,25 \mathrm{~s} . \mathrm{cm}^{-1} ; 1,04$ e $3,78 \mathrm{~s} . \mathrm{cm}^{-1} ;$ 0,98 e $3,82 \mathrm{s.cm}$; 1,08 e $3,57 \mathrm{s.cm}$, respectivamente para os mesmos tratamentos. Portanto, indicando que o estresse que as plantas estavam submetidas era no máximo considerado moderado e de curta duração, tanto para déficit quanto para excesso hídrico temporário. 
TABELA 14 - Somatória de horas de insolação, observado no posto metereológico da Estação Experimental de Pariquera Açu, no período do florescimento ao enchimento completo dos grãos de milho.

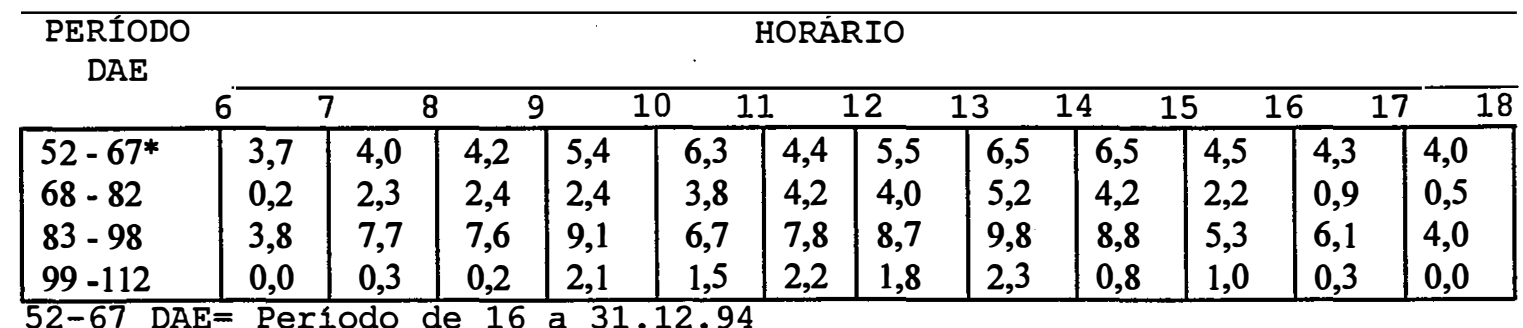

\subsubsection{Eficiência na conversão de matéria seca em grãos}

A razão entre $\circ$ peso dos grãos e $\circ$ peso da matéria seca total que expressa a razão entre a produtividade econômica e biológica é também chamada de índice de colheita. Os resultados do índice de colheita no final do ciclo não apresentaram diferenças significativas para os diferentes tratamentos, Figura 8.

O mesmo ocorreu com a razão entre o peso da matéria seca de grãos e o peso da matéria seca da espiga, Figura 9.

A Figura 10 mostra que a razão entre o peso seco da matéria seca de grãos e o peso seco da somatória do peso seco de folhas e colmos, tiveram comportamento semelhantes 
entre todos os tratamentos. Deve-se também considerar a susceptibilidade desse indice a erros no peso de folhas devido às perdas por senescência, reduzindo sua confiabilidade para análise de produção.

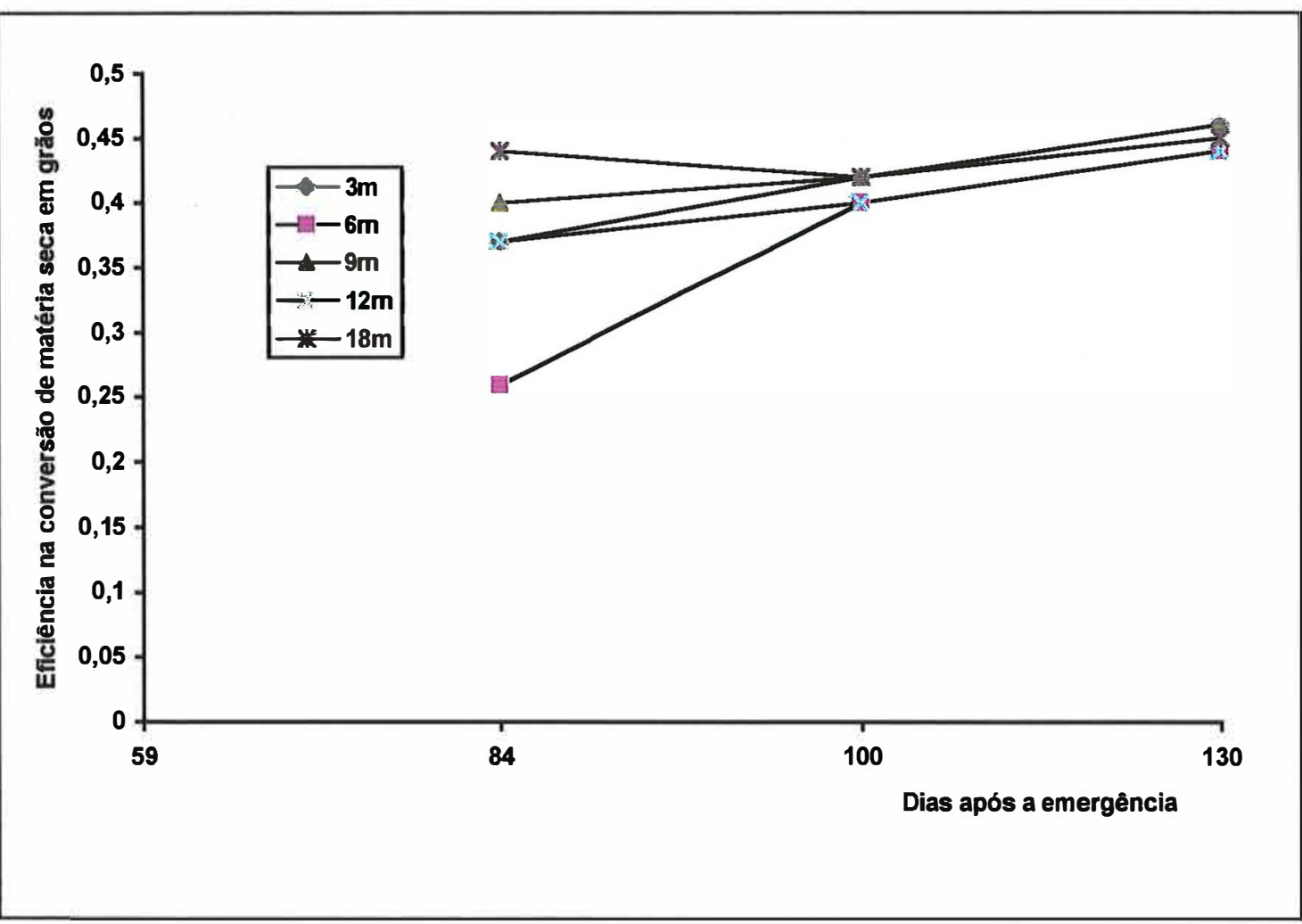

FIGURA 8- Eficiência na conversão da matéria seca total em grãos de milho, cultivado em várzea e submetido a cinco tratamentos de drenagem subterrânea. Pariquera Açu, $94 / 95$. 


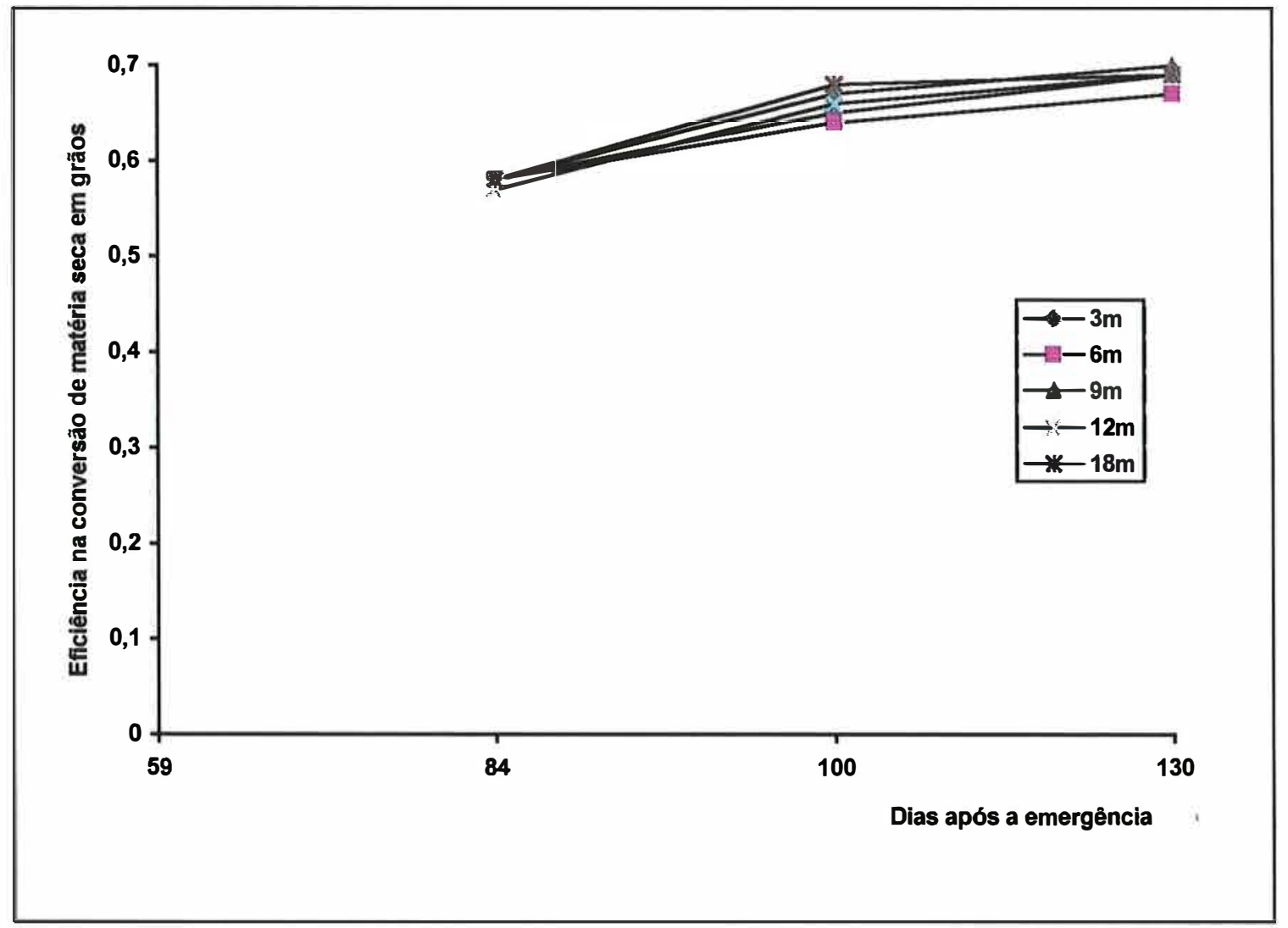

FIGURA 9 - Eficiência na conversão de matéria seca da espiga de milho em grãos, cultivado em várzea e submetido a cinco tratamentos de drenagem subterrânea. Pariquera Açu, $94 / 95$. 


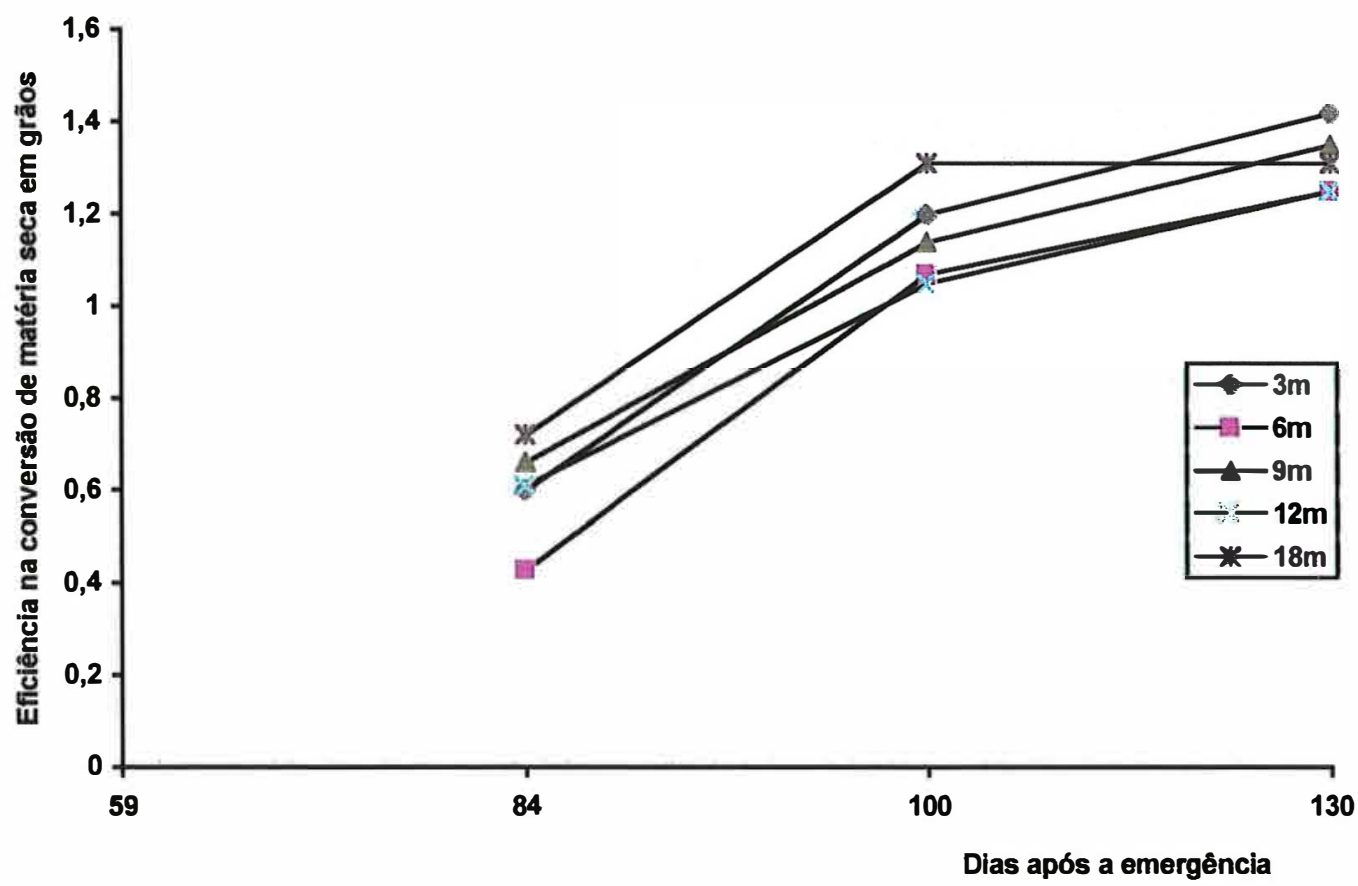

FIGURA 10 - Eficiência na conversão de matéria seca de folhas + colmo em grãos de milho, cultivado em várzea e submetido a cinco tratamentos de drenagem subterrânea. Pariquera Açu, 94/95.

\subsection{Indice de Estresse de Água}

Utilizando-se do conceito de Somatório dos Excedentes de Água acima da profundidade $\mathbf{z} \quad\left(\mathrm{SEW}_{\mathbf{z}}\right)$ introduzido Sieben em 1964, foram avaliados os efeitos da 
flutuação do lençol freático a partir do início do florescimento da planta.

o modelo que mais se ajustou aos tratamentos de espaçamento de drenos, relacionando à produção relativa e o indice $\mathrm{SEW}_{30}$ (SEW para a profundidade de $30 \mathrm{~cm}$ ) foi a equação hiperbólica, apresentado a seguir:

$\mathrm{Y}=0,880 * \mathrm{SEW}_{30} /\left(\mathrm{SEW}_{30}-3,334\right) \quad(\mathrm{r}=-0,953 ; \mathrm{F}=29,9 * *)$

Esses resultados estão coerentes com os obtidos por KANWAR et al. (1988) nos quais a relação que melhor se ajustaram para $\circ$ período do florescimento e enchimento/maturação também foi a hiperbólica. Porém, foram discordantes em relação aos obtidos por COSTA (1994), onde se verificou uma tendência de aumento de produtividade com ○ aumento do índice.

Em vista das limitações do $\mathrm{SEW}_{30}$ no estudo da resposta das culturas à flutuação do lençol freático na qual considera aditivo o estresse imposto à cultura, testou-se, também, no presente experimento o Indice Diário de Stress (IDS) DE HILER et al. (1974) e HILEL (1969). Neste caso, são incorporados conceitos das necessidades de drenagem das culturas (KANWAR, 1988).

Considerando-se a produção grãos obtida no tratamento 3m como referência, ou seja, conduzido do 
florescimento à colheita sem estresse por excesso hídrico, obteve-se os seguintes fatores de suceptibilidade da cultura: $0 ; 0,0649 ; 0,0813 ; 0,0894 ; 0,1069$, respectivamente, para os tratamentos $3 \mathrm{~m}, 6 \mathrm{~m}, 9 \mathrm{~m}, 12 \mathrm{~m}$ e $18 \mathrm{~m}$. Assim, os IDS calculados para esses tratamentos são os seguintes: $0 ; 2,8$; 6,$3 ; 12,0$ e 23,1 .

O modelo que melhor representou a relação entre a produção relativa ao IDS (cm.dias) foi o hiperbólico decrescente. A equação obtida é a seguinte:

$$
Y=0,89596^{*} I D S /(I D S-0,12457) \quad\left(r=-0,927 ; \quad F=12,7^{\star}\right)
$$

Por outro lado, CARTER et al. (1990), MUKHTAR et al. (1990), EVANS et al. (1991), entre outros obtiveram uma relação linear entre a produção relativa do milho e o IDS.

Os resultados de $\mathrm{SEW}_{30}$ e IDS servem como indicadores para simulação de resposta de culturas comerciais cultivadas com ou sem drenagem, parâmetros para dimensionamento de drenos, planejamento do uso da terra e estratégias de manejo de água. Porém, mais pesquisa é necessária para a adoção dessa metodologia nas condições de São Paulo.

Para condições de cultivo comercial, possivelmente, seja importante a combinação com outros índices que expressem a resposta da cultura aos vários 
tipos de estresses. Conforme observado pela Figura 3, há um regime elevado de precipitação na região, com fornecimento hídrico natural nem sempre ideal, acarretando a ocorrência de lixiviação de nutrientes, e $\circ$ favorecimento para $\circ$ aparecimento de pragas e moléstias, além dos problemas de efeito direto do encharcamento do solo.

\subsection{Sistema Radicular}

\subsubsection{Densidade de comprimento}

De acordo com as Tabelas 15, 16, 17, 18 e 19, respectivamente aos $15,30,44,59$ e 84 DAE, apresenta-se o desenvolvimento médio do sistema radicular de milho até a profundidade de $0,70 \mathrm{~m}$ para os tratamentos de drenagem subterrânea na várzea da Estação Experimental de Pariquera Açu.

Verificou-se que as raízes se concentram mais nas camadas superficiais do solo, decrescendo com a profundidade. Segundo RUSSEL (1981) isso ocorre devido à estrutura de desenvolvimento dos sistemas radiculares. As ramificações laterais que se desenvolvem a partir das raízes principais crescem por um período em direção horizontal, embora posteriormente também cresçam para 
baixo. Associa-se, também, à maior concentração de raízes na superficie, o fato de ocorrer nessa camada maior disponibilidade de nutrientes.

Observou-se que o desenvolvimento das raízes, quer na profundidade quer na densidade de comprimento, desde a primeira amostragem, foram significativamente diferentes entre os tratamentos. No entanto, essas diferenças não refletiram no desenvolvimento vegetativo, como se pode constatar anteriormente.

Aos 15 DAE, o tratamento de maior espaçamento (18m) teve o crescimento das raízes tanto em profundidade quanto lateralmente, prejudicado em relação aos demais espaçamentos. Enquanto todos apresentavam algumas raízes até a profundidade de $0,60 \mathrm{~m}$, nele, observou-se somente até a $0,50 \mathrm{~m}$, assim como a densidade de comprimento na profundidade de 0,10 a $0,20 \mathrm{~m}$ foi menor que as demais.

Aos 30 DAE, apesar da grande variabilidade entre os tratamentos e repetições nas primeiras camadas, sobressai a densidade de comprimento de raízes em profundidade 0,50 a $0,70 \mathrm{~m}$, no tratamento com drenagem mais acentuada $(3 \mathrm{~m})$. Apresentou-se maior em relação aos demais, possibilitando à planta, exploração de maior volume de solo, importante em solos de várzeas de fertilidade não adequada, principamente para aqueles elementos bastante móveis como o potássio e mesmo o magnésio. Acrescentando à 
relação de meios para modificar a zona de raízes (SUMNER \& BOSWELL, 1981), pode-se afirmar que para condições de várzea, um meio eficiente é a utilização de sistemas de drenagem também eficientes.

Aos 44 e 59 DAE, a vantagem ressaltada aos $30 \mathrm{DAE}$ do tratamento $3 \mathrm{~m}$ aos demais não mais se nota entre os dois tratamentos melhores drenados $3 \mathrm{~m}$ e $6 \mathrm{~m}$, mas continua desses em relação aos demais.

Aos $84 \mathrm{DAE}$, observou-se uma diferença significativa na densidade de raízes na profundidade $0,60-0,70 \mathrm{~m}$ onde 0 tratamento menos drenado apresentou o menor desenvolvimento.

Por outro lado, de acordo com RUSSELL (1981), as plantas desenvolvem capacidade de crescimento compensatório, como pode-se observar nos resultados das amostragens, aos 59 e 84 DAE (Tabelas 18 e 19 e Figura 11). Nota-se um desenvolvimento significativo na profundidade 0,00 - 0,10 m do tratamento menos drenado em relação aos demais. KLEPPER et al. (1973) verificaram o mesmo fenômeno às condições inadequadas de desenvolvimento radicular em estudos do sistema radicular do algodão por meio do rizotrom. Verificaram que com um potencial matricial de $-0,9 \mathrm{MPa}$, ocorreu um decréscimo na densidade de comprimento de raízes, na profundidade $0-30 \mathrm{~cm}$, de $2,7 \mathrm{~cm} . \mathrm{cm}^{-3}$ para 0,9 $\mathrm{cm} . \mathrm{cm}^{-3}$ indicando a morte anterior de raízes. Entretanto, houve um correspondente aumento na densidade de raízes a 
$1,8 \mathrm{~m}$ de profundidade, que foi de $0,3 \mathrm{~cm} \cdot \mathrm{cm}^{-3}$ para 2,4 $\mathrm{cm} . \mathrm{cm}^{-3}$, indicando a ocorrência de crescimento compensatório.

Em resumo, observou-se o rápido desenvolvimento do sistema radicular no perfil de solo. o crescimento mais intenso se deu no período 30 a $44 \mathrm{DAE}$, especialmente para as camadas mais superficiais $(0-30 \mathrm{~cm})$. Além da questão da presença de água e da profundidade do lençol freático (Figura 3), não houve impedimento mecânico do solo para o desenvolvimento das raízes.

A distribuição porcentual média das raízes de milho, observada no estádio do florescimento e enchimento dos grãos é apresentada na Figura 11. Esses resultados indicam, que sob condições de boa drenagem, o sistema radicular do milho mostrou-se muito superficial quando comparado aos publicados de regiões temperada ou semiáridas (por exemplo, FOLLETT et al., 1974 ou FOTH, 1962), mas semelhantes aos obtidos em terrras altas no Estado de São Paulo (ARRUDA, 1987). 


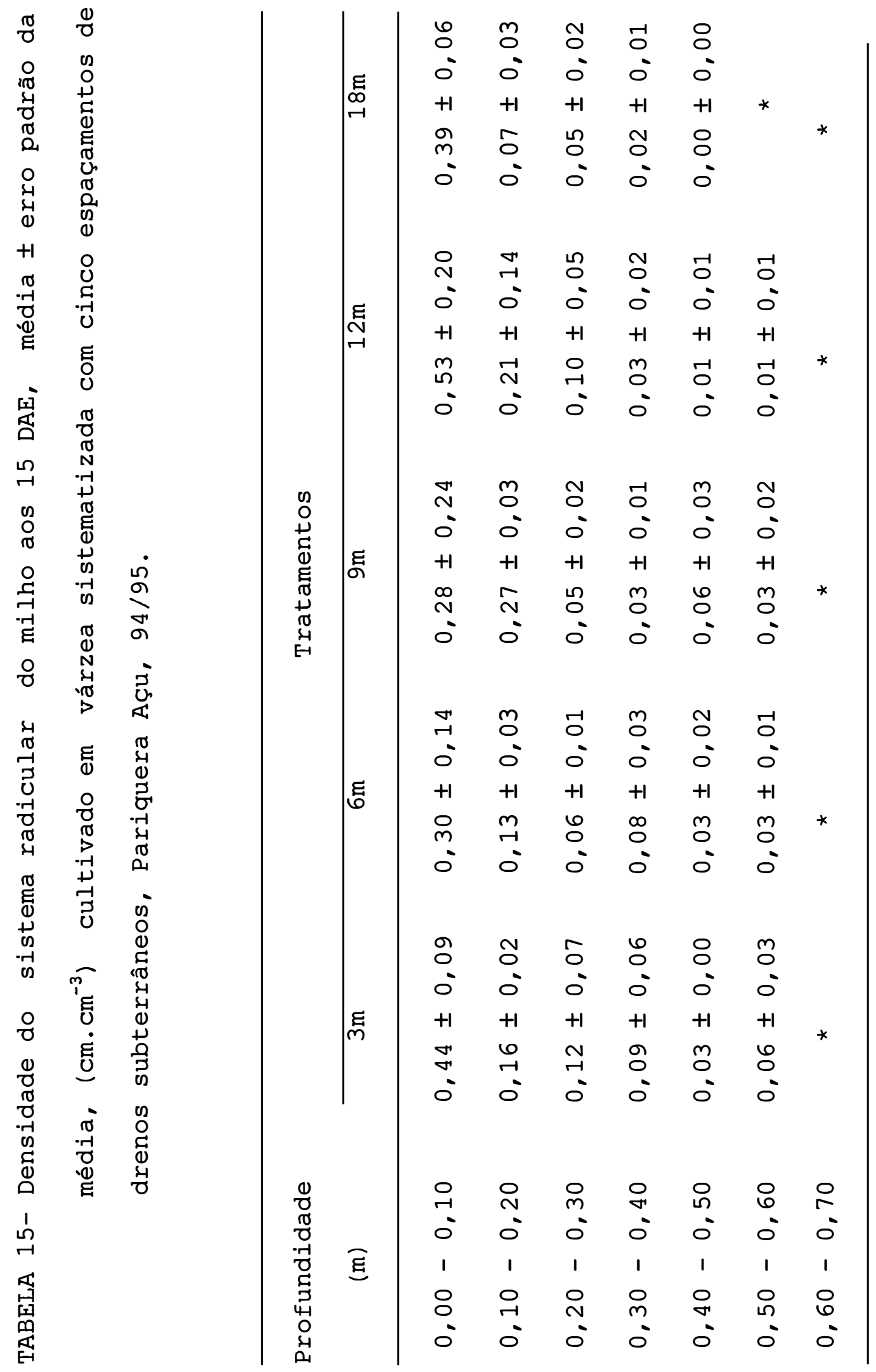




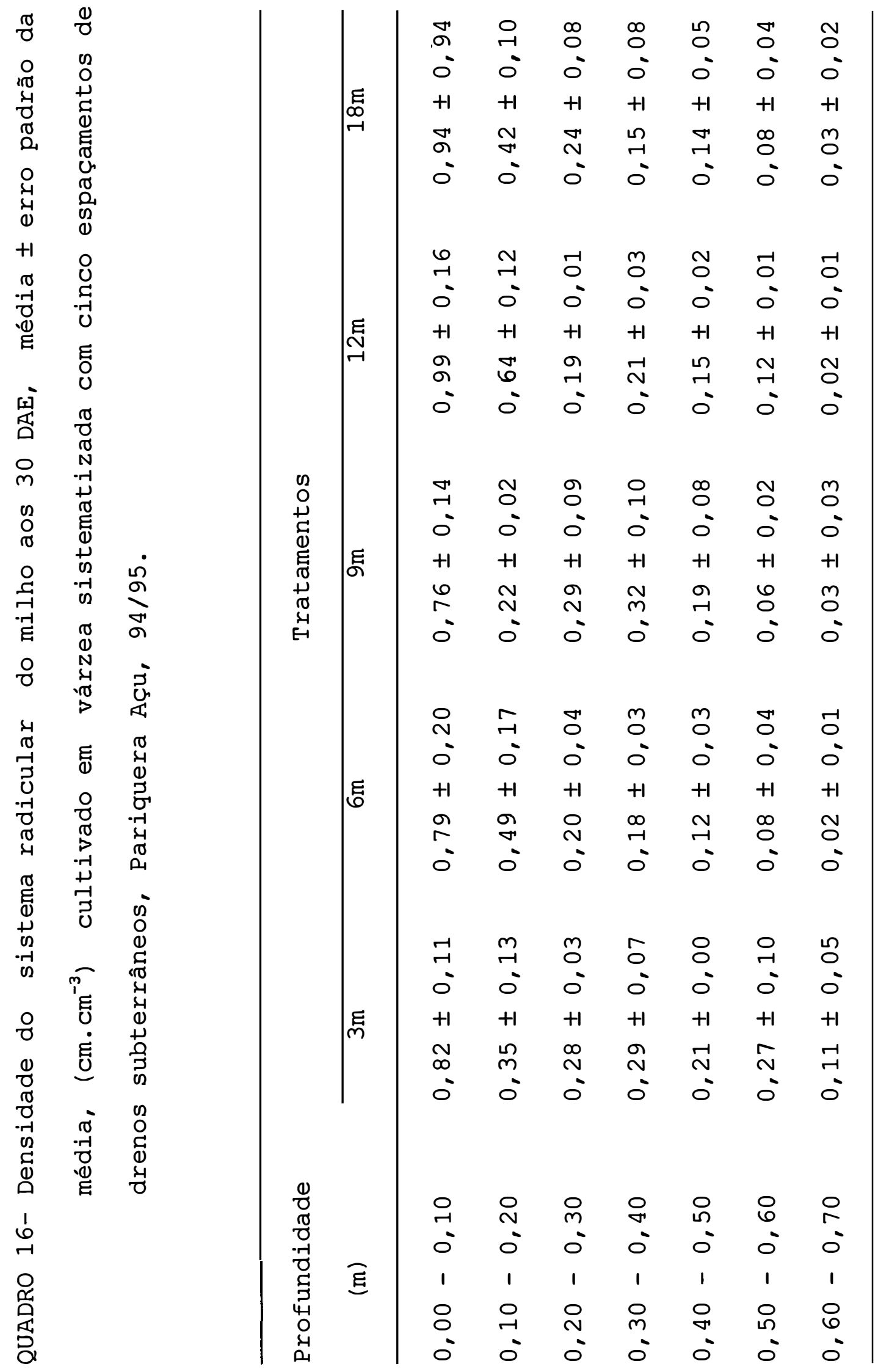




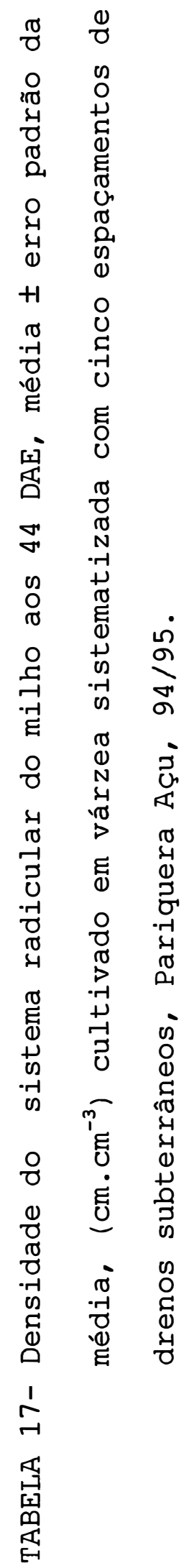

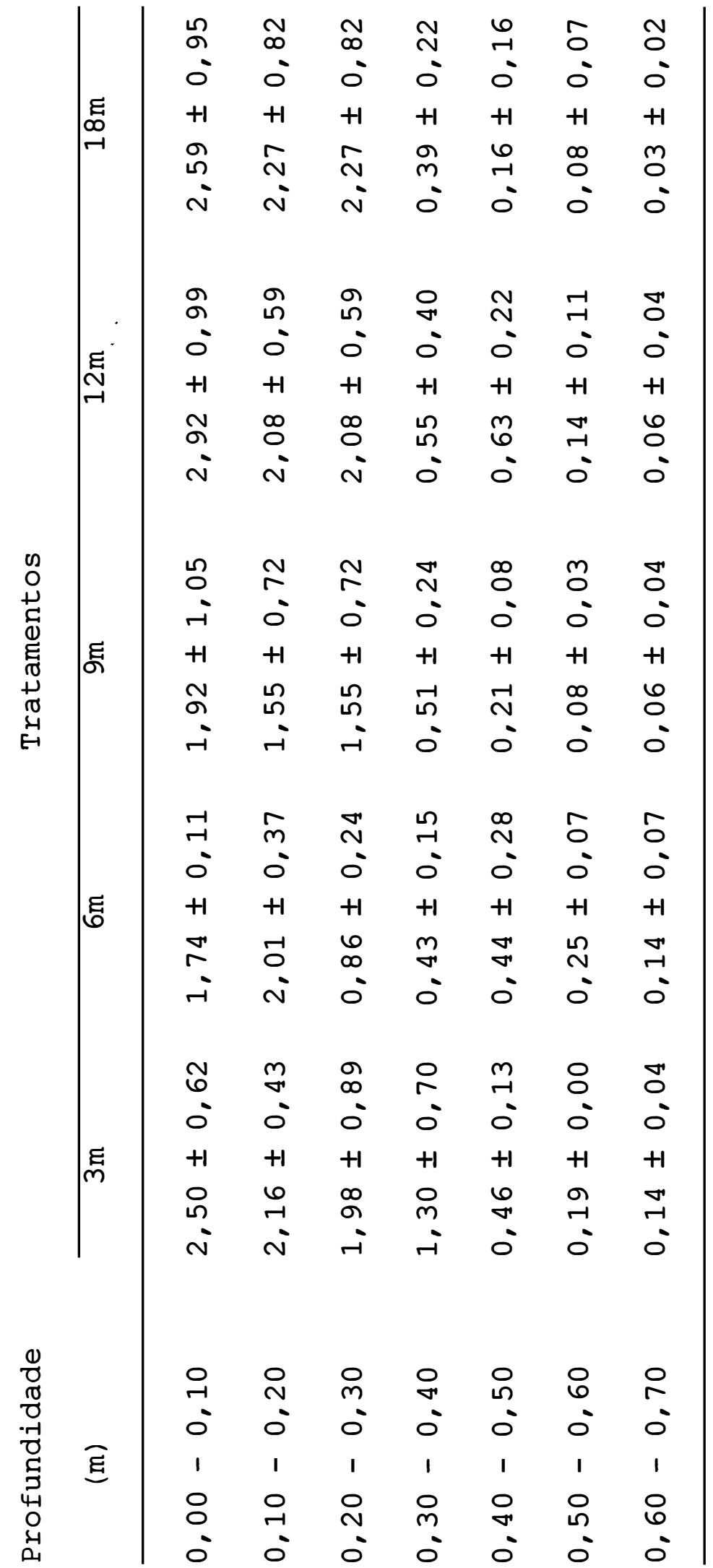




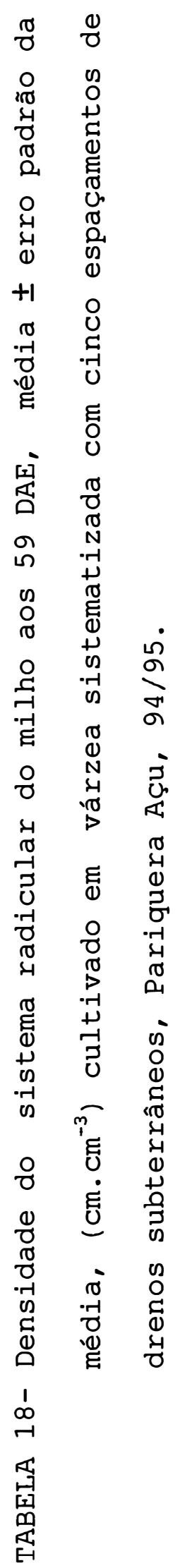

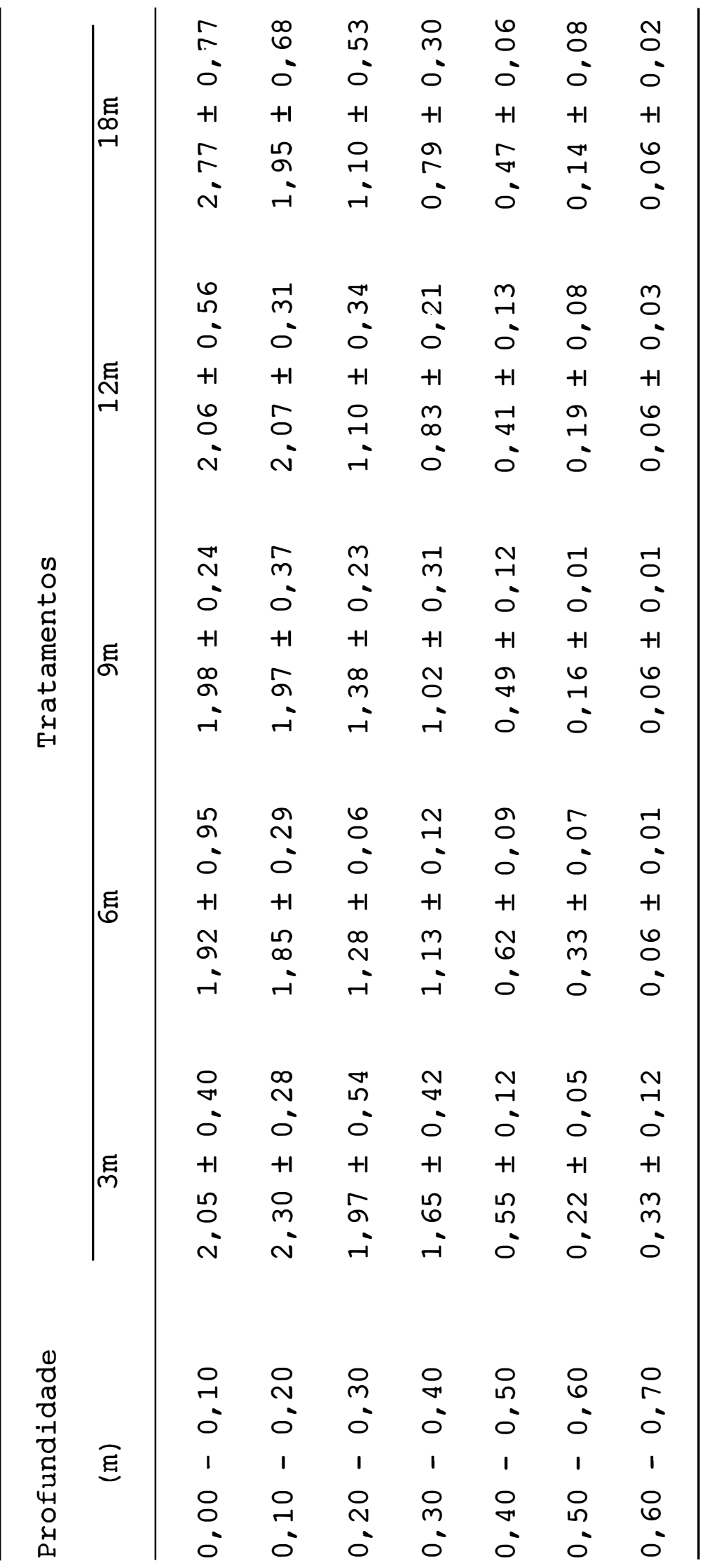




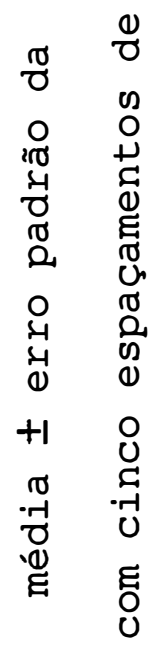

堅

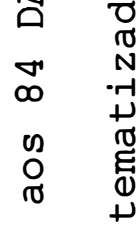

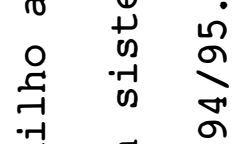

हี

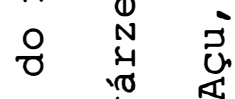

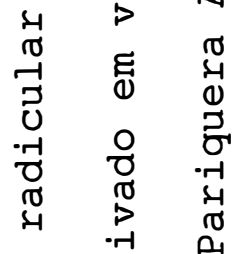

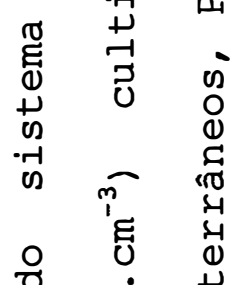

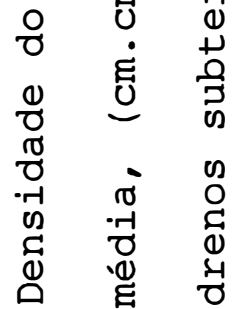

à

空

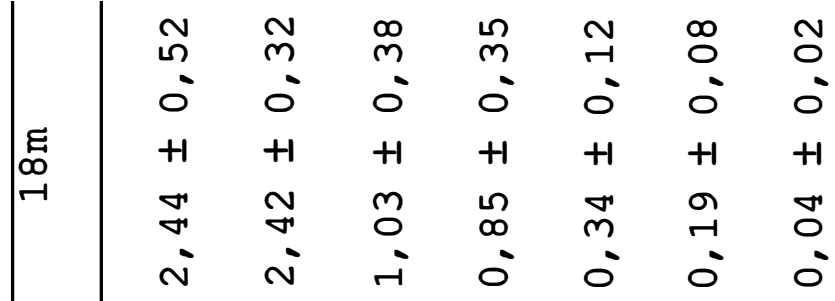

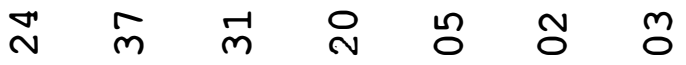

$\circ 0^{\circ} 0^{\circ} 0^{\circ} 0^{\circ} 0^{\circ}$

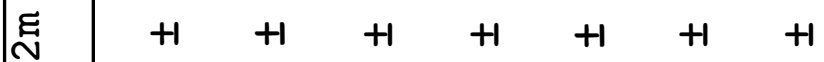

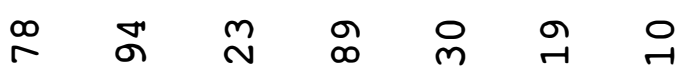

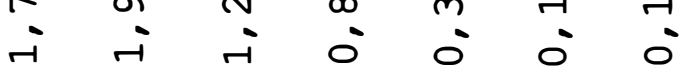

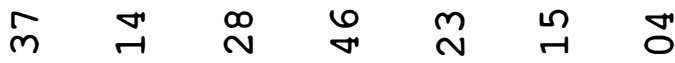

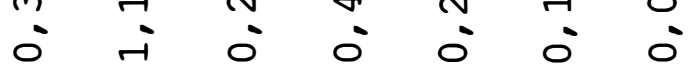

$\begin{array}{lllllll}+1 & +1 & +1 & +1 & +1 & +1\end{array}$

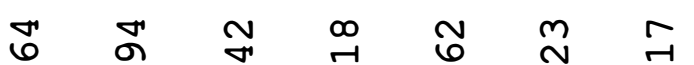

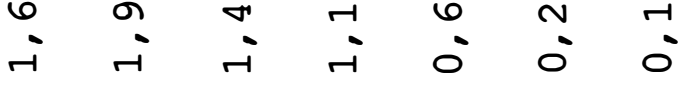

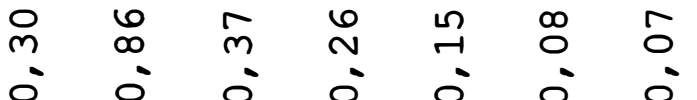

$\begin{array}{lllllll}2 & +1 & +1 & +1 & +1 & +1 & +1\end{array}$

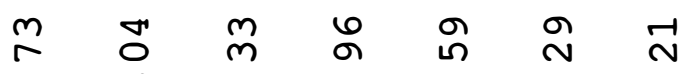

i $i$ i $\begin{array}{lllll} & 0 & 0 & 0 & 0\end{array}$

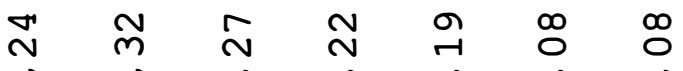

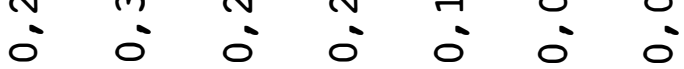

$\begin{array}{lllllll}n+1 & +1 & +1 & +1 & +1 & +1 & +1\end{array}$

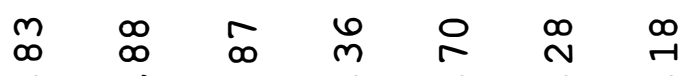

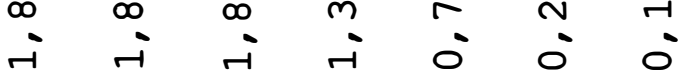

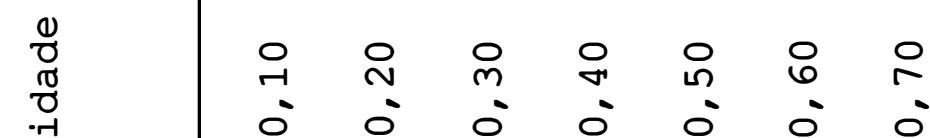

E

$\begin{array}{lllllll}1 & 1 & 1 & 1 & 1 & 1 & 1\end{array}$

$\begin{array}{lllllll}0 & 0 & 0 & 0 & 0 & 0 & 0 \\ 0 & 1 & N & m & \ddots & 0 & 0 \\ 0 & 0 & 0 & 0 & 0 & 0 & 0\end{array}$ 


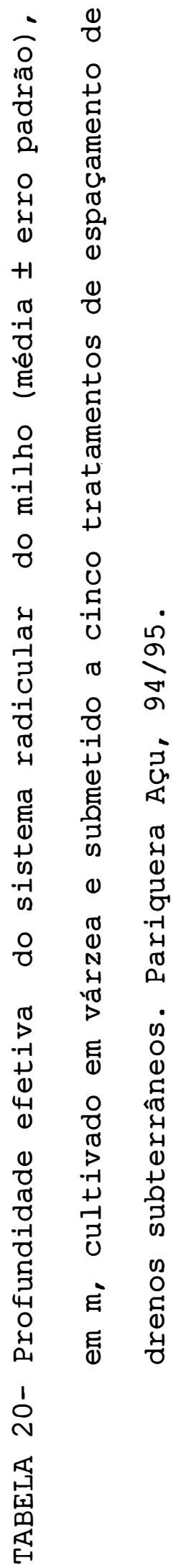

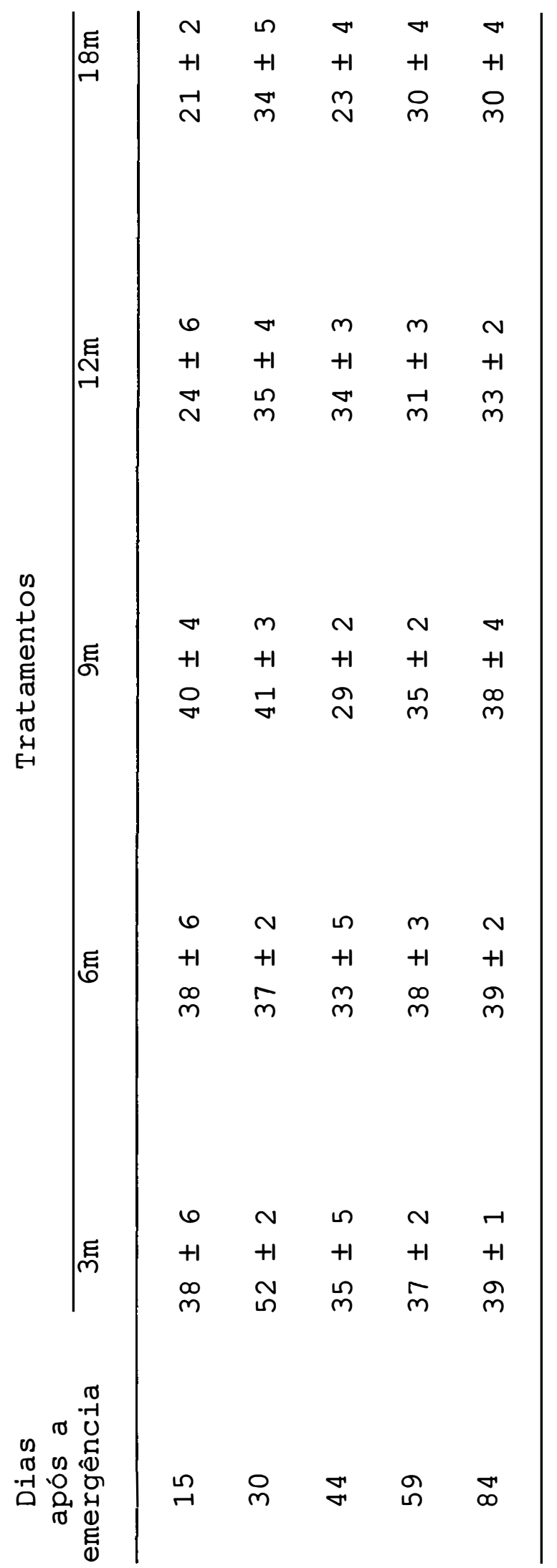



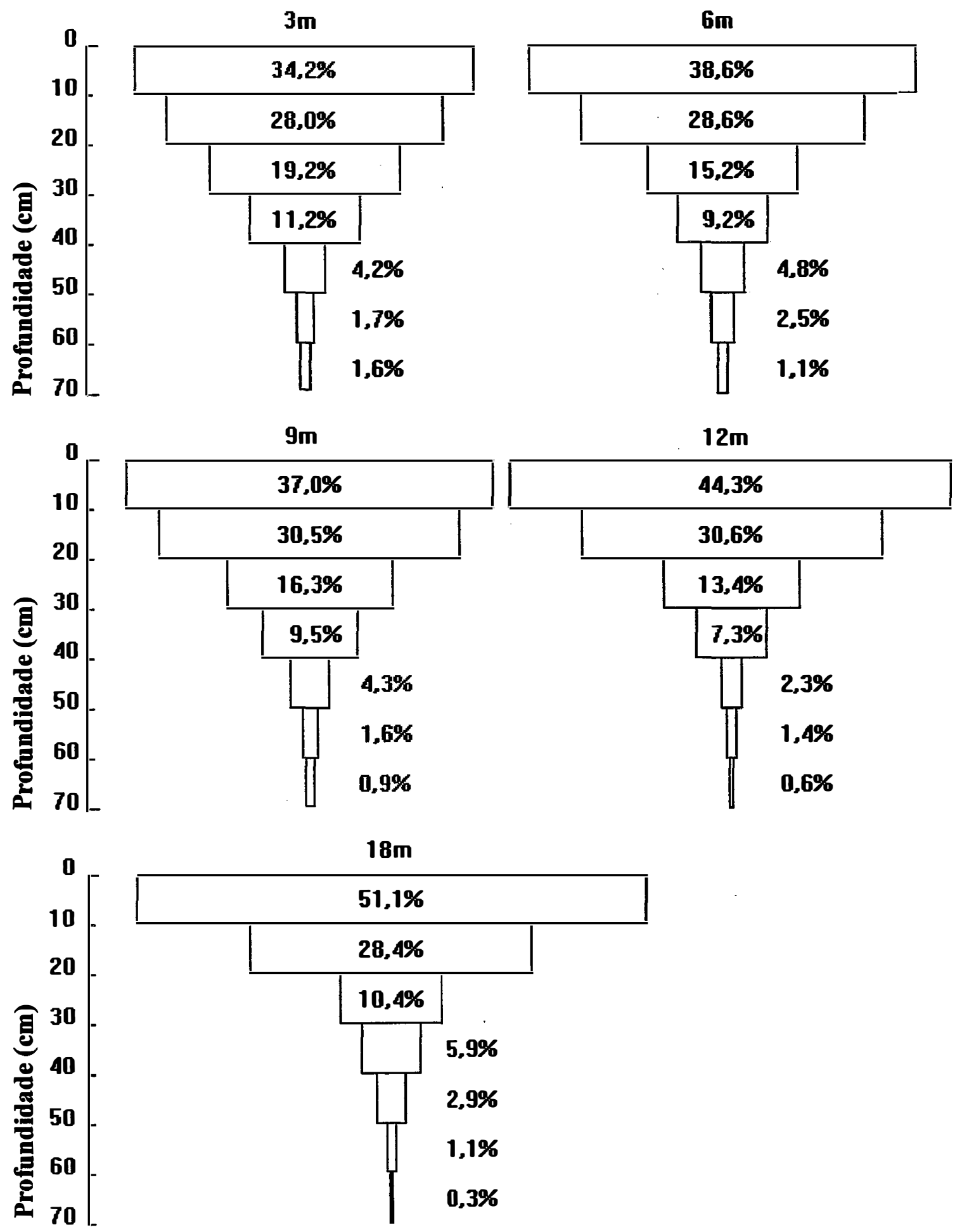

FIGURA 11- Distribuição porcentual média do sistema radicular do milho cultivado em várzea sistematizada com cinco espaçamentos de drenos subterrâneos, no período de 59 a $84 \mathrm{DAE}$, Pariquera Açu, 94/95. 


\subsubsection{Profundidade efetiva}

Com relação à profundidade efetiva do sistema radicular das plantas de milho, Tabela 20, nota-se que aos 15 DAE já se tem indicação de como a cultura se comportaria ao longo de seu desenvolvimento. Com base na densidade de 90\% do peso total das raízes até $0,70 \mathrm{~m}$ de profundidade, aos 15 DAE os tratamentos com drenos espaçados até 9m não variaram entre si, tendo aprofundados em média até $0,38 \mathrm{~m}$, enquanto que, o tratamento $12 \mathrm{~m}$ aprofundou $0,24 \mathrm{~m}$ e $\mathrm{o}$ de $18 \mathrm{~m}$ somente $0,21 \mathrm{~m}$.

Aos 30 DAE, todos os tratamentos tiveram suas raízes com profundidade efetiva maior, mantendo-se a relação anteriormente observada mas com destaque para o tratamento $3 \mathrm{~m}$.

Aos 44 DAE, inversamente, todos os tratamentos tiveram uma diminuição na profundidade efetiva. Provavelmente, o sistema radicular desenvolve-se por fases; primeiramente, as raízes crescem em profundidade se o ambiente assim o permitir, e depois expandem-se lateralmente. Resultados semelhantes foram obtidos por FOTH (1962) em um estudo tentando associar o crescimento da raiz com o da parte aérea. Ele descreve que, inicialmente, o crescimento das raízes ocorre largamente em direção 
diagonal, seguido por um crescimento lateral extensivo. O crescimento lateral foi completado uma a duas semanas antes da emergência da espiga e causou uma marcante uniformidade na densidade de raízes entre 30 e $45 \mathrm{~cm}$ de profundidade. O aparecimento de raízes grossas, de sustentação, ocorreu próximo ao crescimento completo das raízes laterais. o crescimento extensivo de raízes abaixo de $45 \mathrm{~cm}$ ocorreu próximo ao embonecamento, sendo que no estádio de espiga o crescimento de raízes foi completado.

Aos 59 e 84 DAE, já na fase reprodutiva, o sistema radicular manteve-se estabilizado, resultados semelhantes ao obtido por FOTH (1962), e a profundidade efetiva em torno de 0,38 a $0,40 \mathrm{~m}$ para os tratamentos até $9 \mathrm{~m}$ entre drenos e em torno de $0,30 \mathrm{~m}$ para os tratamentos de 12 e $18 \mathrm{~m}$ entre drenos (Figura 12).

Essas concentrações do sistema radicular em camadas superficiais, em geral ocorrem, segundo RUSSELL (1981), devido à estrutura de desenvolvimento dos sistemas radiculares. As ramificações laterais que se desenvolvem a partir das raízes principais crescem por um período em direção horizontal, embora posteriormente também cresçam para baixo. Essa concentração maior na superfície, ocorre mesmo quando os fatores do solo não restringem a sua extensão. 
No entanto, REICHARDT (1981) analisando um grande número de trabalhos que tratam dos efeitos das condições do solo sobre o desenvolvimento de raízes, constatou que, uma conclusão geralmente aceita, é o problema do pequeno crescimento de raízes em solos extremamente intemperizados dos trópicos e subtrópicos.

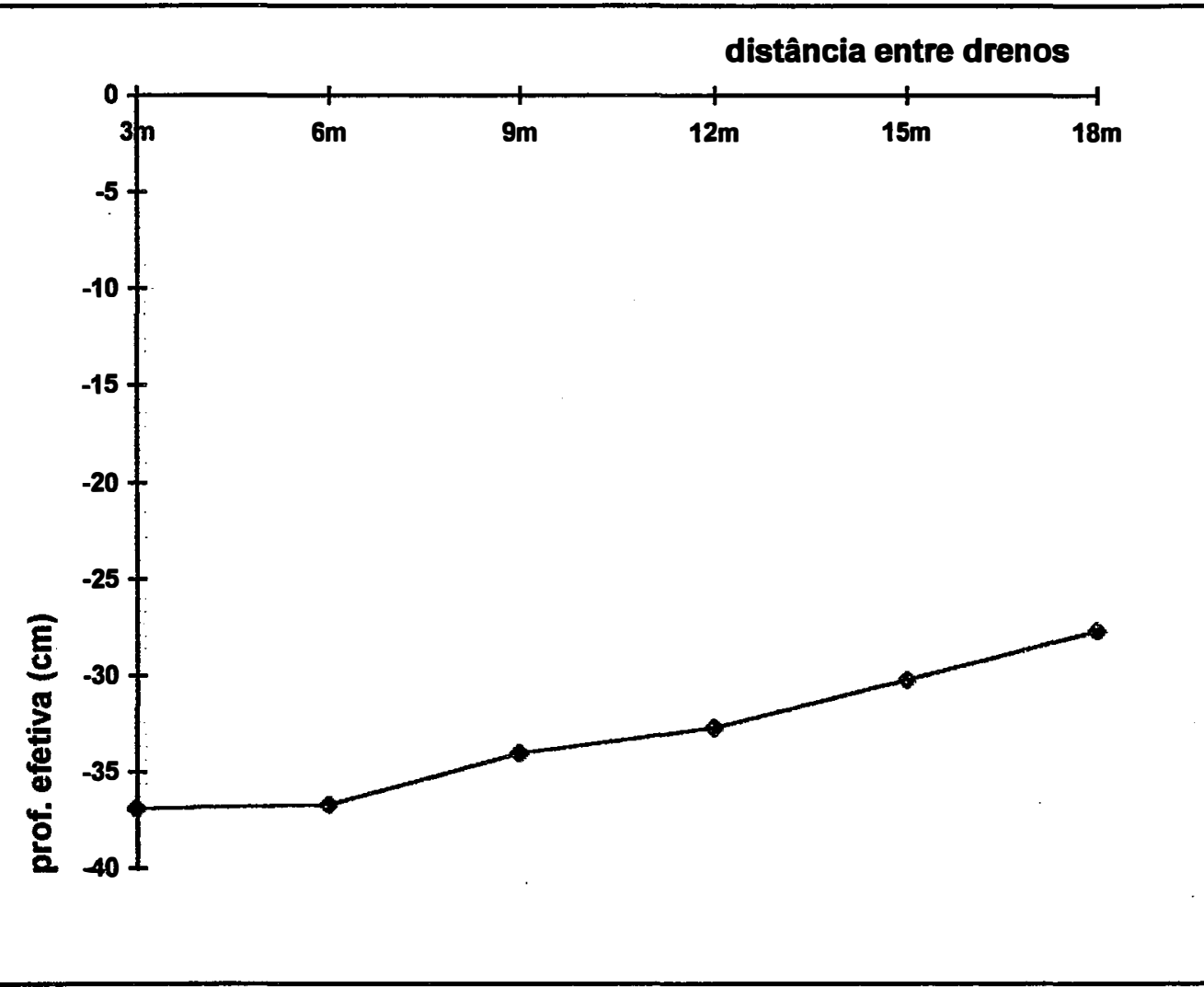

FIGURA 12- Profundidade efetiva média do sistema radicular do milho, no período do florescimento, cultivado em várzea sitematizada com cinco espaçamentos de drenos subterrâneos, Pariquera Açu, 94/95. 


\section{CONCLUSÕES}

Em face dos resultados obtidos com a cultura do milho cultivada em solo orgânica com: várìos espaçamentos: de drenos subterrâneos, no Vale do Ribeira, para as condições do experimento pode-se concluir que:

o método do tensiômetro para monitoramento do lençol freático apresenta resultados semelhantes ao método convencional da leitura direta no poço. Apresenta a vantagem da rápida visualização do comportamento geral do terreno quanto ao escoamento da água, além da facilidade e rapidez nas leituras diárias.

Os espaçamentos entre drenos resultaram em uma diferença média de $15 \mathrm{~cm}$ na profundidade do lençol freático entre os tratamentos de maior e menor distância. As diferenças observadas nas plantas quanto a altura, área foliar, matéria seca, índice de colheita e produção final foram pequenas, porém evidentes e favoráveis aos tratamentos com os drenos mais próximos entre sí. 
Utilizou-se do conceito de "Somatório de Excesso de Água", SEW 30 , de Sieben (1964), para representar o efeito da duração e intensidade do encharcamento do solo quando o lençol. freático era menor de $30 \mathrm{~cm}$ de. profundidade. $\mathrm{SEW}_{30}$ apresentou uma relação hiperbólica decrescente com a produção final dos tratamentos, similar. à obtida por alguns autores e diferente da linear obtida por outros.

o uso do conceito de Indice Diário de Stress (IDS) de Hiler et al (1974), apesar de se mostrar mais informativo do que apenas $\mathrm{SEW}_{30}$, apresentou também uma relação hiperbólica decrescente com a produção final, mas com grau de significância menor.

O sistema radicular da cultura do milho mostrou uma estreita relação entre profundidade efetiva e o nível do lençol freático imposto pelos espaçamentos entre drenos. Os espaçamentos de 18 e $12 \mathrm{~m}$ resultaram na profundidade de 30 e $33 \mathrm{~cm}$, respectivamente. Espaçamentos menores (9 a 3m), propiciaram uma melhor remoção da água de drenagem, resultando em um sistema radicular similar de $39 \mathrm{~cm}$. 


\section{REEER̂̂NCIAS BIBLIOGRÁEICAS}

ALVINO, A. \& ZERBI, G. Water-table level effect on yield of irrigated and unirrigated grain maize. Transactions of the ASAE, St. Joseph, 29(4): 1086-9, 1986.

ANDRADE, L. M. \& REIS, A. E. G. Efeito da profundidade do lençol freático nas culturas de soja, de milho e de arroz. Pesquisa Agropecuária Brasileira, Brasilia, 27 (6) : 923-33, 1992.

ARRUDA, F.B. Uso da água na produção agrícola. In: Simpósio sobre o manejo de água na agricultura, Campinas, 1987. Arais. Campinas, Fundação Cargill, 1987, p.177-199.

BACCHI, O. O. S. Efeitos da compactação sobre o sistema solo-planta em cultura de cana-de-açucar. Piracicaba, 1976. 67p. (Mestrado - Escola Superior de Agricultura "Luis de Queiroz"/USP.

BARBER, S. A.; MACKAY, A.D.; KUCHENBUCH, R.O.; BARRACLOUGH, P.B. Effects of soil temperature and water on maize root growth. Plant Soil, The Hague, 111:267-9, 1988. 
BASSOI,L.H. Lixiviação e acumulação de macronutrientes pelo milho(Zea mays I.) com e sem irrigação suplementar, Botucatu,1990, 102p. (Mestrado-Faculdade de Ciências Agronômicas/UNESP).

BERG, M. van den; LEPSCH, I. F.; SAKAI, E. Solos de planícies aluviais do vale do rio Ribeira do Iguape, SP. I.Padrões de distribuição. Revista Brasileira de Ciência do Solo, Campinas, 11:305-13, 1987.

BLACK, C. A. Relaciones suelo - planta. Buenos Aires, Hemisferio Sur, 1975. 444p.

BENGTSON, R. L.; CARTER, C. E.; MCDANIEL, V.; HAVERSON, B. E. Corn silage response to subsurface drainage on alluvial soil. Transactions of the AsAE, St. Joseph, $27(5): 1391-5,1984$

BOHM, W. Methods of studing root systems. Berlim, SpringerVerlag. 189p. 1979

BROWN, D. A. \& SCOTT, H. don. Dependence of crop growth and yield on root development and activity. In: BARBER, S.A. \& BOULDIN, D. R., ed. Roots, nutrient and water influx, and plant growth. Madison, Soil Science Society of America, 1984. cap. 6, p.101-36. 
CARTER, C. C.; HALVERSON, B.; ROGERS, J. S.; MUSGRAVE, M. Effects of excess soil water on sweet corn yield. Transactions of the ASAE, St. Joseph, 33(4):1203-7, 1990.

CAVAZZA, L. \& ROSSI PISA, P. Effect of water table depth and waterlogging on crop yield. Agricultural Water Management, Amesterdam, 14:29-34. 1988.

CHAUDHARY, T. N.; BHATNAGAR, V. K.; PHINAR, S.S. Corn yield and nutrient uptake as affected by water table depth and soil submergence. Agronomy Journal, Madison, 83: $745-9,1975$.

COSTA, R. N. T. Espaçamento econômico de drenos laterais e a dinâmica do lençol freático sobre o rendimento da cultura de milho (Zea mays L.). Piracicaba, 1994. 88p. (Tese - Esc. Sup. de Agricultura "Luiz de Queiroz"/USP).

CRUCIANI, D. E. Caracterização de coeficientes de drenagem com base nos parâmetros de produção de culturas. Piracicaba, 1981. 99p. (Livre-Docencia - Escola Superior de Agricultura "Luiz de Queiroz"/USP).

DUNCAN, W. G. Maize. In: EVANS, L. T. Crop physiology. Cambridge University Press. London. 23-50. 1977. 
EVANS, L. T. \& WARDLAW, I. F. Aspects of the comparative phisiology of grain yield in cereals. Advances in Agronomy New York, 28:301-59, 1976.

EVANS, R. O.; SKAGGS, R. W.; SNEED, R. E. Normalized crop susceptibility factors for corn and soybean to excess water stress. Transactions of the ASAE, St. Joseph, $33(4): 1153-61,1990$.

EVANS, R. O.; SKAGGS, R. W.; SNEED, R. E. Stress day index models to predict corn and soybean relative yield under high water table conditions. Transactions of the ASAE, St. Joseph, 34(5):1997-2005, 1991.

FOLLETT, R. F.; DOERING, E.J.; REICHMAN, G. A.; BENZ, L. C. Effect of irrigation and water-table depth on crop yields. Agronomy Journal, Madison, 66:304-8, 1974.

FOTH, H. D. Root and top growth of corn. Agronomy Journal, Madison, 54(1):49-52, 1962 .

FUJIWARA, M.; KURACHI, S. A. H.; ARRUDA, F. B.; PIRES, R. C. de M.; SAKAI, E. A técnica de estudo de raizes pelo método do trado. Campinas, Instituto Agronômico, 1994. 9p. (Boletim Técnico, 153). 
GOINS, T.; LUNIN, J.; WORLEY, H. L. Water table effects on growth of tomatoes, snap beans and sweet corn. Transactions of the ASAE, St. Joseph, 9(4):530-3, 1966.

GROHMANN, F. \& QUEIROZ NETO, J. A. Efeito da compactação artificial de dois solos limo-argiloso sobre a penetração das raízes de arroz. Bragantia, Campinas, 25(38):421-31. 1966 .

HARDY, F. Root room. Tropical Agriculture. Trinidad, $51(2): 272-8,1974$

HARRIS, G. L. Effect of mole submergenceon the life of mole channels. Agricultural Water Management, Amesterdam, $8: 361-74,1984$

HILER, E. A. Quantitative evaluation of crop-drainage requeriments. Transactions of the ASAE, St. Joseph, $12(4): 499-505,1969$.

HILER, E. A.; CLARK, R. N.; GLASS, L. J. Effects of water table height on soil aeration and crop response. Transactions of the ASAE, St. Joseph, 14:879-82, 1971. 
HURD, E. A. Growth of roots of seven varieties of spring wheat at high and low moisture levels. Agronomy Journal, Madison, 60:201-5, 1968 .

IVANCKO, C. M. A. M.; PERES FILHO, A.; NOGUEIRA, F.de P.; DONZELI, P.L.; CHIARINI, J.V. Distribuição espacial das várzeas no Estado de São Paulo. Campinas, Instituto Agronômico, 1985. 16p. 9 mapas. (Boletim Científico, 2).

KALITA, P.K. \& KANWAR, R.S. Shallow water table effects on photosynthesis and corn yield. Transactions of the ASAE, St. Joseph, 35 (1):97-104, 1992.

KANWAR, R.S.; BAKER, J.L.; MUKHTAR, S. Excessive soil water effects at various stages of development on the growth and yield of corn. Transactions of the ASAE, St. Joseph, $31(1): 133-41,1988$.

KITAGAWA, Y.; TANAKA, Y.; SORIN, T. Soil management in a drained paddy field for upland crop cultivations. II. Subsurface drainage combined with deep tillage and aplication of organic matter. Bull. of the Nara Agricultural Experiment Station, Nara, 19:57-66. 1988. 
KLEPPER, B.; TAYLOR, H. M.; HUCK, M. G.; FISCUS, E. L. Water relations and growth of cotton in drying soil. Agronomy Journal, Madison, 65:307-10, 1973.

KLEPPER, D. \& ANGHINONI, I. Crescimento radicular e aéreo do milho em vasos em função do nível de fósforo no solo e da localização do adubo fosfatado. Revista Brasileira de Ciência do Solo, Campinas, 19:403-8, 1995.

KRAMER, P. J. Plant and soil water reationships: A modern synthesis. New York, McGraw-Hill. 538p., 1969.

LEPSCH, I. F.; SARAIVA, I.R.; DONZELI, P.L.; MARINHO, M. de A.; SAKAI, E.; GUILLAUMON, J. R.; PFEIFER, R.M.; MATTOS, I. F. da A.; ANDRADE, W. J. de; SILVA, C. E. F. da. Macrozoneamento das terras da região do Rio Ribeira de Iguape, SP. Campinas, Instituto Agronômico, 1990. 181p. ilus., 2 mapas. (Boletim Científico, 19).

MACKAY, A. D. \& BARBER, S. A. Soil moisture effects on root growth and phosphorus uptake by corn. Agronomy Journal, Madison, $77(4): 519-23,1985$. 
MCCLURE, J. W. \& HARVEY, C. Use of radiophosphurus in measuring root growth of sorghums. Agronomy Journal, Madison, 54:457-9, 1962.

MCKEE, G. W. A coefficient for computing leaf area in hibrid corn. Agronomy Journal, Madison, 56:240-1. 1964.

MENGEL, D. B. \& BARBER, S. A. Developmentand distribution of the corn root system under field conditions. Agronomy Journal, Madison, 66:341-4, 1974 .

MILLAR, A. D. Drenagem de terras agricolas: Bases agronômicas. MCGRAW-HILL do Brasil Ltda, 276p., 1978.

MOHAMMAD, F. S. \& SHAGGS, R. W. Effect of drain tube openings on drainage and subirrigation. Transactions of the ASAE, St. Joseph, $27(6): 1455-62,1984$.

MUKTHAR, S.; BAKER, J. L.; KANWAR, R. S. Corn growth as affected by excess soil water. Transaction of the ASAE, St. Joseph, $32(2): 437-42,1990$.

NASSEHZADEH-TABRIZI, A. \& WILLARDSON, L. S. Effects of vibration and soil moisture on the draft of a model mole plow. Transactions of the ASAE, St. Joseph, $24(6): 1490-5,1981$ 
RAIJ, B. van; SILVA, N. M. da; BAtAgLIA, O. C.; QUAGGIO, J. A.; HIROCE, R.; CANTARELLA, H.; BELLINAZZI JÚNIOR, R.; DECHEN, A. R.; TRANI, P. E. Recomendações de adubação e calagem para o Estado de São Paulo. Campinas, Instituto Agronômico, 1985. 107p. (Boletim técnico, 100)

REICHARDT, K. Soil physico-chemical conditions and the development of roots. In: SYMPOSIUM ON THE SOIL/ROOT SYSTEM TO BRASILIAN AGRICULTURE, Londrina, 1980. Proceedings, Edited by R.S. Russell and others. Londrina, IAPAR, 1981. p.103-14.

REICOSKY, D. C.; CAMPBELL, R. B.; DOTY, C. W. Corn plant water stress as influenced by chiseling, irrigation, and water-table depth. Agronomy Journal, Madison, 68 : 499-503, 1976 .

RITTER, W. F. \& BEER, C. E. Yield reduction by controlled flooding of corn. Transactions of the ASAE, St. Joseph, $12: 46-50,1969$

ROSSI, G. \& MUNDSTOCK, C. M. Desenvolvimento do sistema radicular, rendimento e componentes do rendimento do milho (Zea mays L.) sob diferentes níveis de drenagem do solo. Revista Brasileira de Ciência do Solo, Campinas, 4(1):1-4, 1980. 
TOLLENAAR, M. Sink-source relationships during reproductive development in maize. A review Maydica, 12:48-75. 1977.

ULLOA, A.M.C.; LIBARDI, P.L.; REICHARDT, K. Utilização do nitrogênio fertilizante por dois híbridos de milho. Campinas, Fundação Cargill, 1982. 66p.

WILLARDSON, L. S. Drainage coefficients. Transactions of the ASAE, St. Joseph, 25(5):1251-3, 1257. 1982 .

WILLIAMSON, R. E. \& KRIZ, G. J. Response of agricultural crops to flooding, depth of water table and gaseus composition. Transactions of the ASAE, St.Joseph, 13(1): 216-20, 1970. 